Atmos. Chem. Phys., 17, 12197-12218, 2017

https://doi.org/10.5194/acp-17-12197-2017

(c) Author(s) 2017. This work is distributed under

the Creative Commons Attribution 3.0 License.

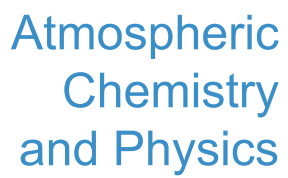

(c) (P)

\title{
Aerosols at the poles: an AeroCom Phase II multi-model evaluation
}

\author{
Maria Sand ${ }^{1,2}$, Bjørn H. Samset ${ }^{1}$, Yves Balkanski ${ }^{3}$, Susanne Bauer ${ }^{2}$, Nicolas Bellouin ${ }^{4}$, Terje K. Berntsen ${ }^{1,5}$, \\ Huisheng Bian ${ }^{6}$, Mian Chin ${ }^{7}$, Thomas Diehl ${ }^{8}$, Richard Easter ${ }^{9}$, Steven J. Ghan ${ }^{9}$, Trond Iversen ${ }^{10}$, Alf Kirkevåg ${ }^{10}$, \\ Jean-François Lamarque ${ }^{11}$, Guangxing Lin ${ }^{9}$, Xiaohong Liu ${ }^{12}$, Gan Luo ${ }^{13}$, Gunnar Myhre ${ }^{1}$, Twan van Noije ${ }^{14}$, \\ Joyce E. Penner ${ }^{15}$, Michael Schulz ${ }^{10}$, Øyvind Seland ${ }^{10}$, Ragnhild B. Skeie ${ }^{1}$, Philip Stier ${ }^{16}$, Toshihiko Takemura ${ }^{17}$, \\ Kostas Tsigaridis $^{2}$, Fangqun Yu ${ }^{13}$, Kai Zhang ${ }^{18,9}$, and Hua Zhang ${ }^{19}$ \\ ${ }^{1}$ Center for International Climate and Environmental Research - Oslo (CICERO), Oslo, Norway \\ ${ }^{2}$ NASA Goddard Institute for Space Studies and Columbia Earth Institute, New York, NY, USA \\ ${ }^{3}$ Laboratoire des Sciences du Climat et de l'Environnement, CEA-CNRS-UVSQ, Gif-sur-Yvette, France \\ ${ }^{4}$ Department of Meteorology, University of Reading, Reading, UK \\ ${ }^{5}$ Department of Geosciences, University of Oslo, Oslo, Norway \\ ${ }^{6}$ Earth System Science Interdisciplinary Center, University of Maryland, College Park, MD, USA \\ ${ }^{7}$ NASA Goddard Space Flight Center, Greenbelt, MD, USA \\ ${ }^{8}$ Directorate for Sustainable Resources, Joint Research Centre, European Commission, Ispra, Italy \\ ${ }^{9}$ Pacific Northwest National Laboratory, Richland, WA, USA \\ ${ }^{10}$ Norwegian Meteorological Institute, Oslo, Norway \\ ${ }^{11}$ National Center for Atmospheric Research, Boulder, CO, USA \\ ${ }^{12}$ Department of Atmospheric Science, University of Wyoming, USA \\ ${ }^{13}$ Atmospheric Sciences Research Center, State University of New York at Albany, New York, USA \\ ${ }^{14}$ Royal Netherlands Meteorological Institute, De Bilt, the Netherlands \\ ${ }^{15}$ Climate and Space Sciences and Engineering, University of Michigan, Ann Arbor, MI, USA \\ ${ }^{16}$ Department of Physics, University of Oxford, Oxford, UK \\ ${ }^{17}$ Research Institute for Applied Mechanics, Kyushu University, Fukuoka, Japan \\ ${ }^{18}$ Max Planck Institute for Meteorology, Hamburg, Germany \\ ${ }^{19}$ Laboratory for Climate Studies, National Climate Center, China Meteorological Administration, Beijing, China
}

Correspondence to: Maria Sand (maria.sand@ cicero.oslo.no)

Received: 13 December 2016 - Discussion started: 10 February 2017

Revised: 23 August 2017 - Accepted: 24 August 2017 - Published: 13 October 2017

\begin{abstract}
Atmospheric aerosols from anthropogenic and natural sources reach the polar regions through long-range transport and affect the local radiation balance. Such transport is, however, poorly constrained in present-day global climate models, and few multi-model evaluations of polar anthropogenic aerosol radiative forcing exist. Here we compare the aerosol optical depth (AOD) at $550 \mathrm{~nm}$ from simulations with 16 global aerosol models from the AeroCom Phase II model intercomparison project with available observations at both poles. We show that the annual mean multi-model median is representative of the observations in Arctic, but that the intermodel spread is large. We also document the geographical distribution and seasonal cycle of the AOD for the
\end{abstract}

individual aerosol species: black carbon (BC) from fossil fuel and biomass burning, sulfate, organic aerosols (OAs), dust, and sea-salt. For a subset of models that represent nitrate and secondary organic aerosols (SOAs), we document the role of these aerosols at high latitudes.

The seasonal dependence of natural and anthropogenic aerosols differs with natural aerosols peaking in winter (seasalt) and spring (dust), whereas AOD from anthropogenic aerosols peaks in late spring and summer. The models produce a median annual mean AOD of 0.07 in the Arctic (defined here as north of $60^{\circ} \mathrm{N}$ ). The models also predict a noteworthy aerosol transport to the Antarctic (south of $70^{\circ} \mathrm{S}$ ) with a resulting AOD varying between 0.01 and 0.02 . The 
models have estimated the shortwave anthropogenic radiative forcing contributions to the direct aerosol effect (DAE) associated with $\mathrm{BC}$ and $\mathrm{OA}$ from fossil fuel and biofuel (FF), sulfate, SOAs, nitrate, and biomass burning from $\mathrm{BC}$ and $\mathrm{OA}$ emissions combined. The Arctic modelled annual mean DAE is slightly negative $\left(-0.12 \mathrm{~W} \mathrm{~m}^{-2}\right)$, dominated by a positive BC FF DAE in spring and a negative sulfate DAE in summer. The Antarctic DAE is governed by BC FF. We perform sensitivity experiments with one of the AeroCom models (GISS modelE) to investigate how regional emissions of $\mathrm{BC}$ and sulfate and the lifetime of $\mathrm{BC}$ influence the Arctic and Antarctic AOD. A doubling of emissions in eastern Asia results in a $33 \%$ increase in Arctic AOD of BC. A doubling of the $\mathrm{BC}$ lifetime results in a $39 \%$ increase in Arctic AOD of BC. However, these radical changes still fall within the AeroCom model range.

\section{Introduction}

The polar regions are relatively free from local sources of anthropogenic climate drivers, but are still experiencing rapid changes to increasing greenhouse gas concentrations, which are distributed globally. These changes are amplified by feedbacks in the system, such as temperature feedbacks and the ice albedo feedback (Pithan and Mauritsen, 2014). The temperature in the Arctic is experiencing increases that are twice the global rate, resulting in reductions in summer sea-ice (Hartmann et al., 2013; Screen and Simmonds, 2010). In the Antarctic, summer sea-ice is increasing, while several interior regions are rapidly losing ice mass (Rignot et al., 2008). The role of aerosols in the ongoing polar climate changes is not well understood. Yang et al. (2014) emphasize the importance of including aerosols in models when simulating the recent changes in the Arctic climate. For instance, the measured decrease in anthropogenic sulfate concentrations in the Arctic over the last decades (Hirdman et al., 2010; Quinn et al., 2009) may have had a warming effect on the Arctic (Navarro et al., 2016). Shindell and Faluvegi (2009) showed that decreasing sulfate and increasing BC concentrations over the last three decades have substantially warmed the Arctic. In general, the climate impacts of aerosols and clouds constitute one of the largest sources of uncertainty in climate models (Boucher et al., 2013). This is true on a global scale and likely for the critical polar regions, where both sensitivities and dynamical processes may differ significantly from global mean values. Reducing these uncertainties is crucial for improving the reliability of future climate projections.

Aerosols perturb the Earth's radiation balance through extinction of solar radiation (McCormick and Ludwig, 1967; Schulz et al., 2006). By scattering solar radiation, aerosols produce a negative DAE at the top-of-the-atmosphere (TOA). Some aerosols such as BC and dust also absorb solar radia- tion, and this absorption can lead to a positive DAE TOA (Bond et al., 2013). For a given aerosol abundance, the magnitude and sign of the DAE depend on the underlying surface albedo (Haywood and Shine, 1995). In the polar regions, the high albedo of snow- and ice-covered surfaces will increase the absorption associated with the DAE for absorbing aerosols (Hansen and Nazarenko, 2004; Bond et al., 2013). Concurrently, deposition of $\mathrm{BC}$ and dust can reduce the surface albedo and promote snowmelt (Flanner et al., 2009; Krinner et al., 2006; Clarke and Noone, 1985). Aerosols also influence the energy balance by changing the optical properties and lifetime of clouds (Twomey, 1977; Albrecht, 1989), and through changes to atmospheric stability (Hansen et al., 1997; Hodnebrog et al., 2014; Samset and Myhre, 2015).

The amount of aerosols emitted into the atmosphere has increased over the industrial era. Myhre et al. (2013) reported on the DAE due to anthropogenic aerosols in AeroCom Phase II. The global model median DAE of the total aerosol effect, taking into account changes to $\mathrm{BC}$, sulfate, OA, biomass burning aerosols, nitrate, and secondary organic aerosols, was estimated at $-0.27 \mathrm{~W} \mathrm{~m}^{-2}$ with an intermodel range of -0.58 to $-0.02 \mathrm{~W} \mathrm{~m}^{-2}$ for the time period 1850 2000. Modifying the results from models with missing SOAs and nitrate by use of results from the other models and scaling the period to $1750-2010$ resulted in a median DAE of $-0.35 \mathrm{~W} \mathrm{~m}^{-2}$.

Most of the aerosols in the polar regions originate from lower latitudes and midlatitudes (Koch and Hansen, 2005; Hirdman et al., 2010). Large-scale planetary circulations in the Northern Hemisphere govern transport into the Arctic. The pronounced seasonal cycle of Arctic AOD typically has a maximum in late winter and spring due to a wintertime build-up in the shallow boundary layer with effective transport and reduced scavenging, often referred to as the Arctic haze (Iversen and Joranger, 1985; Stohl, 2006). The seasonal cycle of Arctic AOD also varies spatially due to changing emissions, composition, and transport patterns. In spring, pollution haze and dust plumes from Asian deserts are most common, while late in the season biomass burning and wildfire smoke from North America and Siberia are observed more frequently (Tomasi et al., 2007). As the Arctic seaice melts and more open water is exposed, emissions of seasalt, dimethylsulfide (DMS), and organic aerosols within the Arctic are expected to increase (Nilsson et al., 2001; Browse et al., 2014).

In the Antarctic, sea-salt particles dominate the coastal sites, which are strongly influenced by the surrounding ocean (Tomasi et al., 2007). In summer, the sulfate from DMS produced by phytoplankton is at its peak, which can also influence the aerosol distribution in the Antarctic (Arimoto et al., 2004). The stations on the Antarctic Plateau, conversely, are mostly influenced by long-range transport in the free troposphere and the subsidence of fine sulfate and methane sulfonic acid (MSA) (Hara et al., 2004; Bigg, 1980; Tomasi et al., 2015). Sea-salt measured here originates mainly from 
marine air transported by large storm events. The Antarctic is also influenced by smoke aerosols transported from South America, Australia, and southern Africa (Fiebig et al., 2009; Stohl and Sodemann, 2010).

The ability of climate models to simulate aerosol burdens in remote regions depends on transport and precipitation, as well as internal aerosol physical and chemical parameterizations, such as wet deposition, oxidation, and microphysics (Shindell et al., 2008; Textor et al., 2006; Zhou et al., 2012; von Hardenberg et al., 2012). Aerosol observations in the polar regions are sparse. Previous comparisons between models and single observations show significant model biases (Stohl et al., 2013; Shindell et al., 2008; Koch et al., 2009). Eckhardt et al. (2015) evaluate sulfate and BC concentrations from different models against a large set of ground-based and aircraft measurements in the Arctic. They find that the aerosol seasonal cycle at the surface is weak in most models and that the concentrations of equivalent $\mathrm{BC}$ and sulfate are underestimated in winter and spring, but improved relative to earlier comparisons. Jiao et al. (2014) compare AeroCom Phase II models with observations of BC in snow in the Arctic. They find that simulated $\mathrm{BC}$ distributions in snow are not well correlated with measurements, but that averaged values over the measurement domain are close to observed. The BC atmospheric residence time in the Arctic varies from 3.7 to 23.2 days in the models, and they suggest that aerosol removal processes are a leading source of variation in model performance in the Arctic. Kristiansen et al. (2016) calculate the aerosol lifetime by using observations of two radioactive isotopes released from the Fukushima nuclear power plant accident: one passive tracer and one that condenses on sulfate particles $\left({ }^{137} \mathrm{Cs}\right)$ that were used as a proxy for sulfate aerosols' fate in the atmosphere. Based on surface measurements taken in the weeks after the release, they derive an

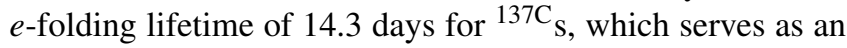
estimate of the lifetime of sulfate. They compare this estimate with 19 AeroCom Phase II models initialized with the same identical emissions of ${ }^{137 C_{S}}$ and the passive tracer. The AeroCom models show a large spread in their estimates lifetimes (4.8 to 26.7 days) and a mean of 9.4 days, which is low compared to the measurements (14.3 days). The underestimation is larger for the northernmost stations, suggesting that the models remove aerosols too quickly and underestimate the transport to the Arctic.

Here we present results from Phase II of the AeroCom model experiment. The goal is to document the seasonal cycle of mean aerosol abundances and the resulting DAE at the poles, predicted by climate models presently in use, and the multi-model spread. The DAE does not include indirect cloud effects or surface albedo modifications. As global aerosol emissions may change rapidly, both in magnitude and geographical distribution, and aerosol abundance observations in the polar regions are sparse, one aim of the present study is to deliver a baseline to which future model studies and observations may be compared.

\section{Methods}

\subsection{Models}

We have used results from 16 global aerosol models that participated in the AeroCom Phase II project (e.g. Myhre et al., 2013) http://aerocom.met.no. The models are NCAR-CAM3.5 (Lamarque et al., 2010, 2012), CAM4-Oslo (Kirkevåg et al., 2013), CAM5.1 (Liu et al., 2012), GISSMATRIX (Bauer et al., 2008), GISS modelE (Koch et al., 2011), GMI-MERRA-v3 (Bian et al., 2009), GOCARTv4 (Chin et al., 2009), HadGEM2 (Bellouin et al., 2011), IMPACT (Lin et al., 2012), INCA (Szopa et al., 2013), ECHAM5-HAM2 (Stier et al., 2005; Zhang et al., 2012b), OsloCTM2 (Skeie et al., 2011), SPRINTARS (Takemura et al., 2005), TM5 (Vignati et al., 2004), GEOS-Chem (Yu and Luo, 2009), and BCC (Zhang et al., 2012a). Model descriptions including model resolution, meteorology, and aerosol microphysics are given in Table S1 in the Supplement.

Each model has provided climate and aerosol simulations using year 2006 meteorology. For present-day simulations emissions for the year 2000 have been used, and for preindustrial runs year 1850 emissions have been used (Lamarque et al., 2010). All AeroCom models include sulfate, BC, primary organic carbon, sea-salt, and mineral dust in their total AOD, and some models also include nitrate and SOA. To report on the individual species, the models have either added double calls to the radiation code (i.e. for each time step the radiation code is called with and without the arguments needed to calculate the given species' forcing) or performed additional runs where each species has been run with preindustrial emissions. However, not all models were able to extract the AOD for the individual species. Table 1 lists the models and the species reported by each model. The individual species include BC (from fossil fuel, biofuel, and biomass burning emissions), sulfate, total OA (from fossil fuel, biofuel, and biomass burning emissions), nitrate, SOA, sea-salt, and dust. Here, organic aerosols refer to the total mass of organic compounds in the aerosol (both primary and secondary). For a comprehensive documentation on OA and SOA treatment in the AeroCom Phase II models, see Tsigaridis et al. (2014). The AOD is a measure of the total extinction (scattering and absorption) of sunlight as it passes through the atmosphere. In this study we use the AOD at $550 \mathrm{~nm}$ wavelength. The models have estimated AOD as a combination of aerosol abundances and optical properties, which is why AOD can be reported in the months in which there is no actual sunlight. The DAE is calculated as the difference in TOA SW radiation between simulations with present-day and preindustrial emissions of aerosols and their precursors (under all-sky conditions). Results are available for total aerosol forcing, as well as for individual aerosol species (BC from fossil fuel and biofuel emissions (FF), sulfate, total OA FF, nitrate, SOA, and $\mathrm{OA}$ and $\mathrm{BC}$ combined 
Table 1. List of the models used in this study and which species they have reported.

\begin{tabular}{|c|c|c|c|c|c|c|c|c|c|c|c|c|c|c|c|}
\hline & \multicolumn{8}{|c|}{ Aerosol optical depth } & \multicolumn{7}{|c|}{ Direct aerosol effect } \\
\hline & Total & Sulfate & $\mathrm{BC}$ & OA & SOA & Nitrate & Dust & Sea-salt & Total & Sulfate & $\mathrm{BC} F \mathrm{~F}$ & $\mathrm{OA} \mathrm{FF}$ & $\mathrm{BB}$ & SOA & Nitrate \\
\hline CAM4-Oslo & $\mathrm{x}$ & $\mathrm{x}$ & $\mathrm{x}$ & $\mathrm{x}$ & & & $\mathrm{x}$ & $\mathrm{x}$ & $\mathrm{x}$ & & & & & & \\
\hline HadGEM2 & $\mathrm{x}$ & $\mathrm{x}$ & $\mathrm{x}$ & $\mathrm{x}$ & $\mathrm{x}$ & $\mathrm{x}$ & $\mathrm{x}$ & $\mathrm{x}$ & $\mathrm{x}$ & $\mathrm{x}$ & $\mathrm{x}$ & $\mathrm{x}$ & $\mathrm{x}$ & & $\mathrm{x}$ \\
\hline ECHAM5-HAM & $\mathrm{x}$ & $\mathrm{x}$ & $\mathrm{x}$ & & $\mathrm{x}$ & & $\mathrm{x}$ & $\mathrm{x}$ & $\mathrm{x}$ & $\mathrm{x}$ & $\mathrm{x}$ & $\mathrm{x}$ & $\mathrm{x}$ & $\mathrm{x}$ & \\
\hline OsloCTM2 & $\mathrm{x}$ & $\mathrm{x}$ & $\mathrm{x}$ & $\mathrm{x}$ & $\mathrm{x}$ & $\mathrm{x}$ & $\mathrm{x}$ & $\mathrm{x}$ & $\mathrm{x}$ & $\mathrm{x}$ & $\mathrm{x}$ & $\mathrm{x}$ & $\mathrm{x}$ & $\mathrm{x}$ & $\mathrm{x}$ \\
\hline SPRINTARS & $\mathrm{x}$ & $\mathrm{x}$ & $\mathrm{x}$ & $\mathrm{x}$ & $\mathrm{x}$ & & $\mathrm{x}$ & $\mathrm{x}$ & $\mathrm{x}$ & $\mathrm{x}$ & $\mathrm{x}$ & $\mathrm{x}$ & $\mathrm{x}$ & & \\
\hline GISS-MATRIX & $\mathrm{x}$ & & & & & & & & $\mathrm{x}$ & $\mathrm{x}$ & $\mathrm{x}$ & $\mathrm{x}$ & & & \\
\hline GISS-modelE & $\mathrm{x}$ & $\mathrm{x}$ & $\mathrm{x}$ & $\mathrm{x}$ & $\mathrm{x}$ & & $\mathrm{x}$ & $\mathrm{x}$ & $\mathrm{x}$ & $\mathrm{x}$ & $\mathrm{x}$ & $\mathrm{x}$ & $\mathrm{x}$ & & \\
\hline CAM5.1 & $\mathrm{x}$ & $\mathrm{x}$ & $\mathrm{x}$ & $\mathrm{x}$ & $\mathrm{x}$ & & $\mathrm{x}$ & $\mathrm{x}$ & $\mathrm{x}$ & $\mathrm{x}$ & $\mathrm{x}$ & $\mathrm{x}$ & $\mathrm{x}$ & $\mathrm{x}$ & \\
\hline $\mathrm{BCC}$ & $\mathrm{x}$ & $\mathrm{x}$ & $\mathrm{x}$ & $\mathrm{x}$ & & & & & $\mathrm{x}$ & $\mathrm{x}$ & $\mathrm{x}$ & $\mathrm{x}$ & $\mathrm{x}$ & & \\
\hline GMI-MERRA-v3 & $\mathrm{x}$ & $\mathrm{x}$ & $\mathrm{x}$ & $\mathrm{x}$ & & $\mathrm{x}$ & & $\mathrm{x}$ & $\mathrm{x}$ & $\mathrm{x}$ & $\mathrm{x}$ & $\mathrm{x}$ & $\mathrm{x}$ & & $\mathrm{x}$ \\
\hline GEOS-Chem & $\mathrm{x}$ & & & & & & $\mathrm{x}$ & $\mathrm{x}$ & $\mathrm{x}$ & $\mathrm{x}$ & $\mathrm{x}$ & $\mathrm{x}$ & $\mathrm{x}$ & $\mathrm{x}$ & $\mathrm{x}$ \\
\hline GOCART-v4 & $\mathrm{x}$ & $\mathrm{x}$ & $\mathrm{x}$ & $\mathrm{x}$ & & & $\mathrm{x}$ & $\mathrm{x}$ & $\mathrm{x}$ & $\mathrm{x}$ & $\mathrm{x}$ & $\mathrm{x}$ & $\mathrm{x}$ & & \\
\hline NCAR-CAM3.5 & $\mathrm{x}$ & & & & & & & & $\mathrm{x}$ & $\mathrm{x}$ & $\mathrm{x}$ & $\mathrm{x}$ & $\mathrm{x}$ & & $\mathrm{x}$ \\
\hline IMPACT & $\mathrm{x}$ & & & & & & & & $\mathrm{x}$ & $\mathrm{x}$ & $\mathrm{x}$ & $\mathrm{x}$ & $\mathrm{x}$ & $\mathrm{x}$ & \\
\hline INCA & $\mathrm{x}$ & $\mathrm{x}$ & $\mathrm{x}$ & $\mathrm{x}$ & & & $\mathrm{x}$ & $\mathrm{x}$ & $\mathrm{x}$ & $\mathrm{x}$ & $\mathrm{x}$ & $\mathrm{x}$ & $\mathrm{x}$ & & $\mathrm{x}$ \\
\hline TM5-V3 & $\mathrm{x}$ & $\mathrm{x}$ & $\mathrm{x}$ & $\mathrm{x}$ & & $\mathrm{x}$ & $\mathrm{x}$ & $\mathrm{x}$ & $\mathrm{x}$ & & & & & & \\
\hline
\end{tabular}

Table 2. List of the Arctic and Antarctic stations with ground-based measurements of AOD. Data for Tiksi, Andenes, Yakutsk, Bonanza Creek, Resolute Bay, and Kangerlussuaq are taken from the AERONET database (http://aeronet.gsfc.nasa.gov/) and data from Ny-Ålesund, Barrow, and Alert are from Stone et al. (2014) and Tomasi et al. (2015).

\begin{tabular}{lll}
\hline Stations & Coordinates and altitude (a.m.s.l.) & Measurement period \\
\hline Tiksi & $71^{\circ} \mathrm{N}, 128^{\circ} \mathrm{E}$, Alt 0 m & $2010-2012,2014$ \\
Andenes & $69^{\circ} \mathrm{N}, 16^{\circ} \mathrm{E}$, Alt $379 \mathrm{~m}$ & $2002,2008-2011,2013,2014$ \\
Yakutsk & $61^{\circ} \mathrm{N}, 129^{\circ} \mathrm{E}$, Alt $118 \mathrm{~m}$ & $2004-2015$ \\
Bonanza Creek & $64^{\circ} \mathrm{N}, 148^{\circ} \mathrm{W}$, Alt $150 \mathrm{~m}$ & $1994-1997,1999-2015$ \\
Resolute_Bay & $74^{\circ} \mathrm{N}, 94^{\circ} \mathrm{W}$, Alt 40 m & $2004,2006,2008-2015$ \\
Kangerlussuaq & $66^{\circ} \mathrm{N}, 50^{\circ} \mathrm{W}$, Alt 320 m & $2008-2015$ \\
Ny-Ålesund & $78^{\circ} \mathrm{N}, 11^{\circ} \mathrm{E}$, Alt $5 \mathrm{~m}$ & $2001-2011$ \\
Barrow & $71^{\circ} \mathrm{N}, 156^{\circ} \mathrm{W}$, Alt $8 \mathrm{~m}$ & $2001-2011$ \\
Alert & $82^{\circ} \mathrm{N}, 62^{\circ} \mathrm{W}$, Alt $210 \mathrm{~m}$ & $2004-2011$ \\
Neumeyer & $70^{\circ} \mathrm{S}, 8^{\circ} \mathrm{W}$, Alt 40 m & $2000-2007$ \\
Troll & $72^{\circ} \mathrm{S}, 2^{\circ} \mathrm{E}$, Alt $1309 \mathrm{~m}$ & $2007-2013$ \\
South Pole & $90^{\circ} \mathrm{S}, 0^{\circ} \mathrm{E}$, Alt $2835 \mathrm{~m}$ & $2001-2012$ \\
\hline
\end{tabular}

from biomass burning (BB) emissions. Hereafter we will use the term "BC" for total BC (from fossil fuel, biofuel, and biomass burning emissions) and $\mathrm{BC}$ FF for anthropogenic $\mathrm{BC}$ (from fossil fuel and biofuel emissions), and the same is used for total OA. For AOD we report BC (and OA) only, and for DAE we distinguish between $\mathrm{BC} F F$, OA FF, and biomass burning, the latter consisting of emissions from both $\mathrm{BC}$ and OA. For information on the radiative transfer schemes of the individual models, see Stier et al. (2013), their Table 2, and the aerosol model references in Myhre et al. (2013), their Table 2. Uncertainties in calculating the radiative impact of aerosols are linked to the vertical distribution of aerosols (Samset et al., 2013; Kipling et al., 2016). A comparison of the aerosol vertical extinction coefficient from $11 \mathrm{Ae}$ roCom models to CALIPSO has been performed in Koffi et al. (2016) showing that about half of the models capture the mean aerosol vertical distribution. The models generally perform better over ocean than land ( 9 of 11 models reproduce the aerosol mean vertical distribution over ocean), while the models underestimate the mean aerosol distribution over land. The annual mean multi-model mean absolute error is $11 \%$, but the bias depends highly on model, season, and region. The negative bias is especially pronounced in spring and summer, in source regions in Africa and Asia dominated by biomass burning ( -17 to $-26 \%$ bias) and dust ( -8 to $-23 \%)$.

Even if the models used meteorology for the year 2006, there is some intermodel variability in the simulated wind. Some models are nudged to different sets of reanalysis, while others have used different prescribed meteorology data sets; see Table S1. Three models (NCAR-CAM3.5, CAM4-Oslo, and CAM5.1) have calculated the meteorology online, i.e. with free-running meteorological fields. In CAM4-Oslo the meteorology is calculated based on the CAM4 aerosol ex- 
tinction and cloud droplet fields, which do not differ between preindustrial and present-day simulations. The two other models have been run for several years to account for the year-to-year variability, and the reported simulations are based on a 5-year average. The fields (wind, temperature, humidity) are not identical for the preindustrial simulations and the present-day simulations in these two models. The calculated aerosol-induced climate response in the polar regions will therefore be due to a combination of differences in emissions and in transport and lifetime. One model (GISS modelE) has duplicate 6-year runs with both nudged winds and free-running winds for preindustrial and presentday conditions, and we find that the difference in the Arctic fraction of the transported tracers between the nudged and the free wind simulations is small. The difference varies between 0.1 and $1.0 \%$ for most species (up to $2.0 \%$ for a few species), for both preindustrial and present-day simulations. Another study with the CAM5.3 MAM4 model finds a significant difference in BC concentrations on a global scale between nudged and free-running winds (Liu et al., 2016), while the differences between the nudged and unnudged runs in a study with ECHAM-HAM were small (von Hardenberg et al., 2012). Nevertheless, it did not make much difference for the ensemble results as to whether we included or excluded the three models that generated their own winds, and we have therefore decided to include these models in the analysis.

There is no unique definition of the Arctic region and here we have defined the Arctic as the region north of $60^{\circ} \mathrm{N}$, a definition found in other studies (Shindell and Faluvegi, 2009; AMAP, 2011). To avoid a large influence from the Southern Ocean we have defined the Antarctic as the region south of $70^{\circ} \mathrm{S}$.

\subsection{Comparison with observations}

\subsubsection{AERONET}

We have compared the modelled seasonal cycle of AOD in the grid box of each model in which the respective station is located with ground-based measurements from 12 stations in the Arctic and Antarctic from the AErosol RObotic NETwork (AERONET) http://aeronet.gsfc.nasa.gov/ (Holben et al., 1998). The locations for each station are plotted in Fig. 3, and the coordinates and measurement years for each station are given in Table 2. For Barrow, Alert, and Ny-Ålesund, we have used monthly mean climatology derived from daily mean of spectral AOD reported in Stone et al. (2014). For the three stations in Antarctica, one coastal (Neumayer), one mid-altitude (Troll), and one plateau (South Pole) monthly mean climatology are taken from Tomasi et al. (2015).

\subsubsection{MODIS}

Due to the high reflectance over bright surfaces, obtaining reliable satellite retrieval of AOD is difficult at the poles. Glantz et al. (2014) compared AOD $555 \mathrm{~nm}$ from the Moderate Resolution Imaging Spectroradiometer (MODIS) Aqua collection 5 Level 2 (Remer et al., 2005) over (dark) ocean areas around Svalbard with available AERONET groundbased measurements at Svalbard (Longyearbyen, $78.2^{\circ} \mathrm{N}$, $15.6^{\circ} \mathrm{E}$; Hornsund, $77.0^{\circ} \mathrm{N}, 15.6^{\circ} \mathrm{E}$ ) for the period 2003 2011. They found comparable values in the summer season (JJA) $(0.041 \pm 0.025$ for MODIS and $0.043 \pm 0.024$ for AERONET) and early autumn (September) $(0.035 \pm$ 0.021 for MODIS and $0.038 \pm 0.021$ for AERONET), but larger differences in spring $(0.115 \pm 0.069$ for MODIS and $0.093 \pm 0.050$ for AERONET). The spring differences are partly explained by diverse air masses causing inhomogeneous aerosol geographical distributions. Glantz et al. (2014) conclude that satellite AOD retrievals in the Arctic marine atmosphere vary within the expected uncertainties of MODIS retrieval over ocean and can be of use to climate model validation. We have compared the MODIS AOD values with the AeroCom models averaged over the same area $\left(75-82^{\circ} \mathrm{N}\right.$, $10^{\circ} \mathrm{W}-40^{\circ} \mathrm{E}$ ), illustrated in Fig. 3 (in blue). For details on the retrieval, see Glantz et al. (2014).

\subsubsection{CALIOP}

We have compared modelled AOD with retrieved AOD from the Cloud-Aerosol LIdar with Orthogonal Polarization (CALIOP) on board the Cloud-Aerosol Lidar and Infrared Pathfinder Satellite Observations (CALIPSO) satellite (Winker et al., 2013). CALIOP is an active nadir-looking backscattering lidar. It distinguishes clouds and aerosols by using the total backscatter radiation measured at $1063 \mathrm{~nm}$ combined with the linear depolarization at $532 \mathrm{~nm}$ (Liu et al., 2009). Because it is an active instrument, CALIOP can retrieve aerosol and cloud vertical profiles in the day and at night, and can measure over the highly reflective surfaces in the Arctic. However, daytime retrievals are affected by the noise from scattering of solar radiation and are therefore less accurate than night-time retrievals (Winker et al., 2009). In the Arctic, there are no night-time observations in May, June, and July which complicates the interpretation of spring and summer retrievals. CALIOP reports AOD by integrating the aerosol extinction coefficient from all detected layers over a given location. Thin aerosol layers in the Arctic often have backscattering values below the detection threshold of CALIOP and the column AOD can therefore be underestimated (Rogers et al., 2014). Omar et al. (2013) found that retrieved AOD from AERONET stations was $25 \%$ higher compared to CALIOP AOD for AOD less than 0.1. CALIOP has an inclination angle of about $98.14^{\circ}$ and therefore has no data points above $82^{\circ} \mathrm{N}$. 

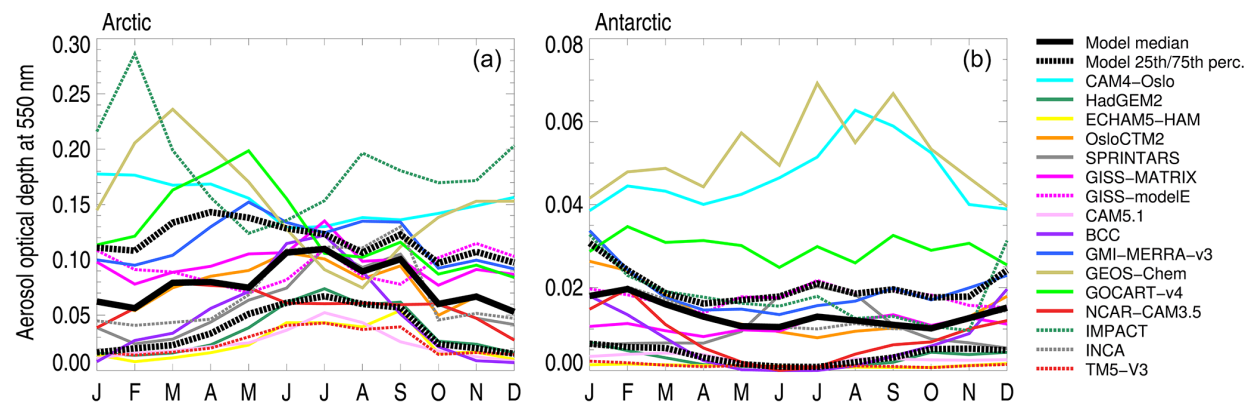

Figure 1. Mean seasonal cycle of the Arctic $\left(60-90^{\circ} \mathrm{N}\right)$ (a) and Antarctic $\left(70-90^{\circ} \mathrm{S}\right)$ (b) total AOD. The different colours represent the different AeroCom Phase II models. The black solid line is the model median and the dashed line is the 25th/75th percentile.

The AeroCom models ran simulations for the year 2006 (with emissions for the year 2000), while we compared AOD with observations from different available years in the period 2000-2015. Comparing 2006 AOD values from CALIOP (only available July-December) with the 2007-2012 average, we find that 2006 is representative of the average (values varies $0-36 \%$ ).

\section{Results}

Here we present AOD and DAE results from the Arctic (defined as $\left.60-90^{\circ} \mathrm{N}\right)$ and the Antarctic $\left(70-90^{\circ} \mathrm{S}\right)$ regions. We compare the simulated seasonal AOD to ground-based measurements from a selection of stations in the Arctic and Antarctic. We also compare the modelled AOD with a retrieval from MODIS over the Svalbard ocean region and with CALIOP. We then document the model-simulated regional patterns for each aerosol species.

\subsection{Aerosol optical depth}

Figure 1 shows the seasonal cycle of the total AOD in the Arctic and the Antarctic, for all the AeroCom Phase II models. Values are for present-day conditions, i.e. emissions representative of the year 2000. The model-median AOD (Fig. 1, thick black line) has a summer maximum and a winter minimum at both poles, but there is a large variation among the different models. For the Arctic, the spread is larger in winter and early spring and smaller during the summer months. A few models suggest an earlier Arctic AOD maximum in winter (IMPACT) and early spring (GEOS-Chem and GOCART). For GEOS-Chem and GOCART this maximum is dominated by natural aerosols (sea-salt and dust, respectively, as shown in Fig. 9). The higher values of AOD in CAM-Oslo are linked to efficient vertical transport in deep convective clouds, which exaggerates the amount of aerosols in the upper troposphere (and poleward transported aerosols). Note that modelled AOD is calculated from simulated aerosol distributions, and can therefore be reported even for months in which there is no actual sunlight.

\subsubsection{Comparisons with measurements at both poles}

We have compared the seasonal cycle of modelled AOD with measurements from nine Arctic stations (details in Table 2), shown in Fig. 2. The AERONET mean (a climatology for all available years) is shown as a red line, and the model median is shown as a thick black line. The yellow line represents the year 2006, in which this was available. The AeroCom models are shown as thin grey lines (for individual models, see Fig. S1 in the Supplement). The root mean square error and the correlation factor are shown for each site. We have calculated the root mean square error (RMSE) as the square root of the average of the difference between the model median and AERONET values for each month. The values ranges from 0.02 (Ny-Ålesund, Kangerlussuaq, and Andenes) to 0.07 (Bonanza Creek). Alert, Ny-Ålesund, Barrow, and Resolute Bay show the typical maximum in springtime AOD. Some models also show this peak, but the model median fails to capture the observed high spring AOD. The correlation factor for these stations is low ( -0.08 to 0.27 ), except for Ny-Ålesund (0.63). Figure 3 shows the type of aerosol in terms of AOD that the models simulate for each station in spring (MAM) (JJA average in Fig. S2). Ny-Ålesund is dominated by sea-salt in spring, and the total AOD is larger than the other stations. There is a better agreement between measurements and models during the summer season when the observed AOD and its variability is lower. Bonanza Creek experienced unusually high August values in 2004, 2005, and 2009, resulting in a large SD. Here, the 2006 values for AERONET are closer to the model median in summer, but not in early spring. Tiksi station has the best correlation between AERONET and the model median (0.86). This station has a maximum in AOD in summer, with large influences of organic aerosols from biomass burning (Fig. S2). Averaged over all nine stations, the annual mean AERONET AOD is $27 \%$ higher compared to the model median AOD (excluding months without measurements). The correlation coefficient between the AeroCom and the AERONET monthly mean is $0.68(P<0.05)$. We would expect the spring peak in AOD to be stronger at the surface than for the total column. The 

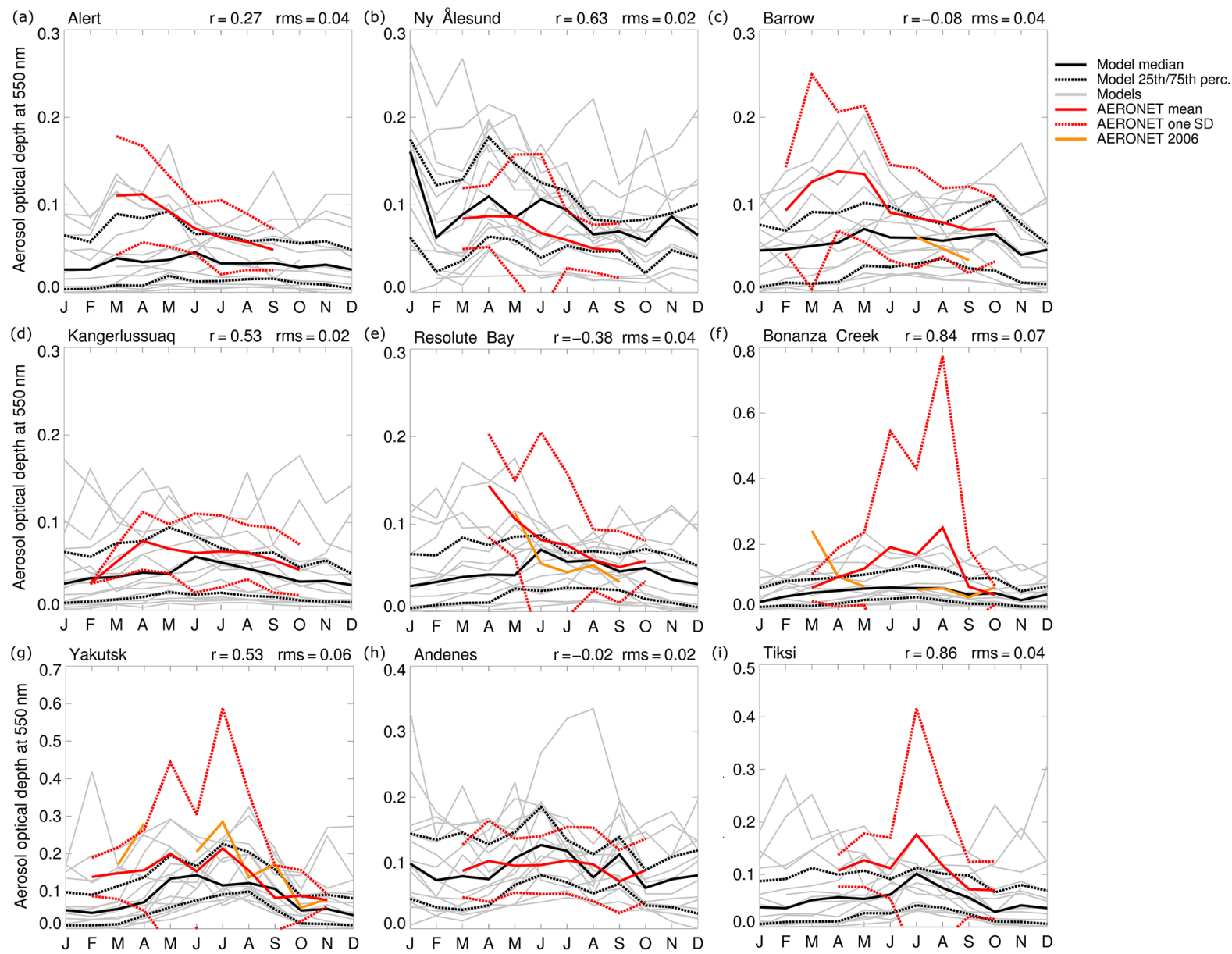

Figure 2. Seasonal cycle of model-median AOD compared to observations for nine Arctic stations: (a) Alert $\left(82^{\circ} \mathrm{N}, 62^{\circ} \mathrm{W}\right)$, (b) Ny-Ålesund $\left(78^{\circ} \mathrm{N}, 11^{\circ} \mathrm{E}\right),(\mathbf{c})$ Barrow $\left(71^{\circ} \mathrm{N}, 156^{\circ} \mathrm{W}\right),\left(\right.$ d) Kangerlussuaq $\left(66^{\circ} \mathrm{N}, 50^{\circ} \mathrm{W}\right)$, (e) Resolute Bay $\left(74^{\circ} \mathrm{N}, 94^{\circ} \mathrm{W}\right)$, (f) Bonanza Creek $\left(64^{\circ} \mathrm{N}\right.$, $\left.148^{\circ} \mathrm{W}\right),(\mathrm{g})$ Yakutsk $\left(61^{\circ} \mathrm{N}, 129^{\circ} \mathrm{E}\right),(\mathbf{h})$ Andenes $\left(69^{\circ} \mathrm{N}, 16^{\circ} \mathrm{E}\right)$, and (i) Tiksi $\left(71^{\circ} \mathrm{N}, 128^{\circ} \mathrm{E}\right)$. The black solid line is the model median and the black dashed line is the 25th/75th percentile. Models are shown in thin, grey lines. The red solid line is the observational mean and the dashed red line is 1 SD from mean values. Measurements for (a-c) are taken Stone et al. (2014), (d-i) are from AERONET stations. Yellow lines are AOD measurements for the year 2006 (only available at a few stations).

age of Arctic air and its amplitude of the seasonal cycle with highest values in spring decrease strongly with altitude (Stohl, 2006), and the observed spring AOD is highest near the surface (Stone et al., 2010).

Figure 4 shows the spring (MAM) and summer (JJA) AOD for each model averaged over the nine Arctic stations, together with the measured AERONET AOD. As is apparent from the correlation coefficient $(0.68)$ and the plots, the multi-model average is not a bad representation of the observed AOD, but the models vary altogether by a factor of 5-6 in magnitude. GOCART and GEOS-Chem are the models closest to the observations in summer, and GMI-MERRA and IMPACT are the closest models in spring.

Retrievals of AOD from the MODIS satellite directly over snow and sea-ice are not available due to the high reflectivity of these surfaces. Glantz et al. (2014) have provided spatial averages of MODIS AOD $555 \mathrm{~nm}$ over (darker) ocean areas around Svalbard over a 9-year period (see Sect. 2). In our comparison, we have included this 9-year average to take into account the interannual spread in the data, even though the AeroCom models have simulated 1 year only. Figure 5a shows AOD over the Arctic Ocean $\left(75-82^{\circ} \mathrm{N}, 10^{\circ} \mathrm{W}-40^{\circ} \mathrm{E}\right)$ from MODIS retrieval 2003-2011 from Glantz et al. (2014) compared with the AeroCom models from April to September. The retrieved AOD is approximately 0.1 in spring, but the uncertainty range is large: $0.115 \pm 0.069$ for MODIS and $0.093 \pm 0.050$ for AERONET (mean AOD $\pm 1 \mathrm{SD}$ ). The retrieved AOD decreases over summer through to September. The AeroCom model mean also show a decrease throughout the year, but the slope is not as steep compared to MODIS. Some of the models shown in Fig. 5b) do have a steeper slope (GOCART, GISS-MATRIX, and GEOS-Chem). In the MODIS data the influence from large forest fire events and volcanic eruptions in summer has been removed to represent 


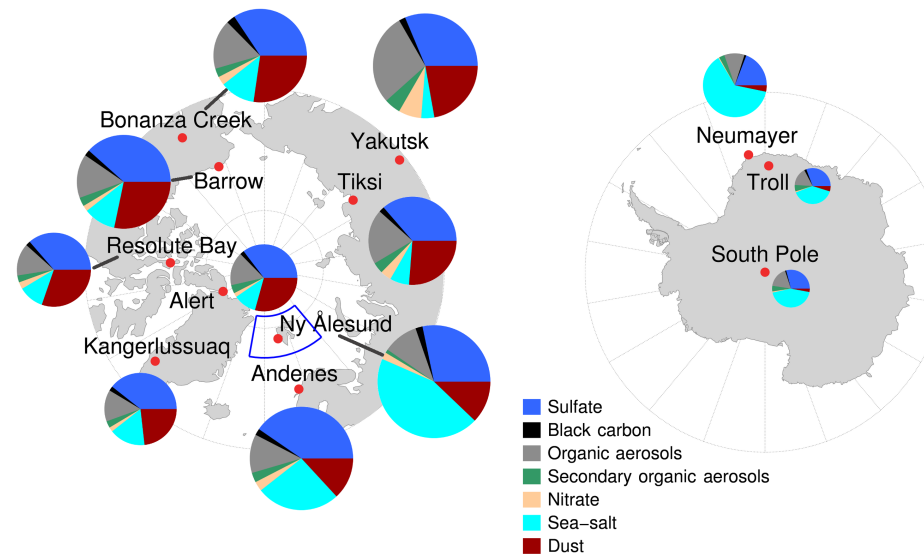

Figure 3. The locations of the stations (red dots) with AOD measurements used in this study and the MODIS area (blue square). The circles show the modelled AOD species MAM average for each station. The area of the circles is scaled to the model median total AOD.
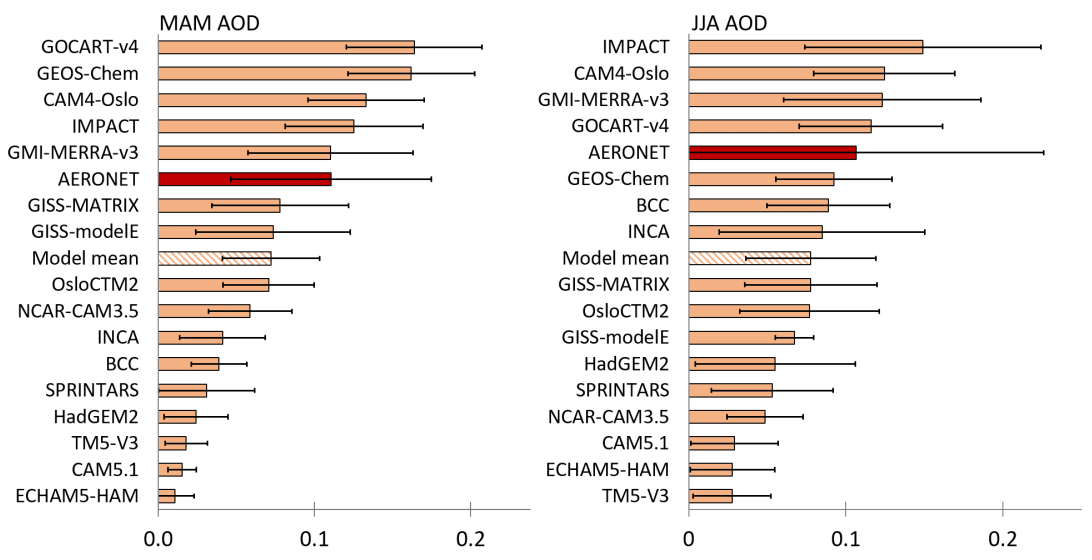

Figure 4. Multi-model AOD averaged for the spring (MAM) and summer (JJA) for the nine Arctic AERONET stations in Fig. 2 (details Table 2). The red bar is the average observation over the nine stations and the striped bar is the multi-model average. The error bars represent $1 \mathrm{SD}$.

background conditions, and this might be part of the reason why the models show higher values in summer compared to MODIS.

We have compared total AOD with the vertical integral of the monthly mean elastic backscatter at $532 \mathrm{~nm}$ from CALIOP. Figure 6 shows the seasonal cycle of AOD532 nm retrieval from CALIOP for the years 2006-2011 averaged over $60-82^{\circ} \mathrm{N}$ compared to the AeroCom models screened by CALIOP availability (which is why June has zero numbers north of $60^{\circ} \mathrm{N}$ ). The summer months are therefore dominated by biomass burning emissions at the southernmost latitudes. For all months except September, the model median lies within the range of the CALIOP retrievals. The correlation coefficient between the model median monthly mean and the CALIOP monthly mean is 0.75 .

Figure 7 shows the measured seasonal cycle of AOD from three Antarctic stations (Neumayer, Troll, and the South Pole) compared to the AeroCom models. The Neumayer site is located closest to the ocean and has the highest variabil- ity among the models. The correlation factor at Neumayer is 0.37 , higher than at Troll $(-0.26)$ and the South Pole $(-0.04)$. Most models seem to be in the lower range of the observations. Tomasi et al. (2015) report multi-year sets of ground-based sun-photometer measurements conducted at nine Antarctic sites. For the high-altitude sites on the Antarctic Plateau (Dome Concordia $75^{\circ} \mathrm{S}$ and South Pole $90^{\circ} \mathrm{S}$ ) AOD is very stable, mainly ranging from 0.02 to 0.04 . These values are slightly higher than the median AeroCom Phase II AOD (0.01).

Figure 8 shows a box plot of the annual mean AOD in the Arctic and Antarctic for total aerosols and for the individual components (sulfate, $\mathrm{BC}$ from all sources, OA from all sources, SOA, nitrate, sea-salt, and dust). Model-median total AOD is 0.07 in the Arctic (with a model range of 0.020.2 ), with the largest contribution to Arctic AOD from sulfate $(45 \%)$. In the Antarctic the total AOD is 0.01 (0.0010.05 ) with sulfate being the largest model median component. However, sea-salt shows a large range with the 75th 

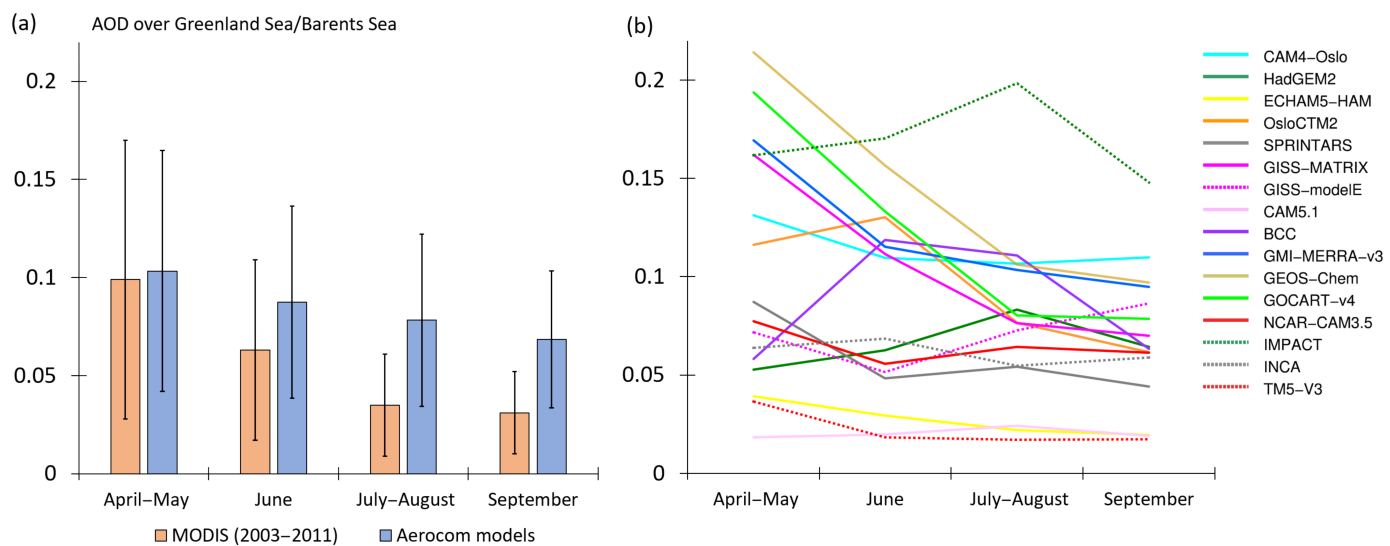

Figure 5. AOD over the Arctic Ocean (75-82 ${ }^{\circ} \mathrm{N}, 10^{\circ} \mathrm{W}-40^{\circ} \mathrm{E}$ ) from (a) MODIS retrieval 2003-2011 median (orange) compared to the AeroCom Phase II model mean (blue) and (b) the individual models. The error bars in (a) represent 1 SD.

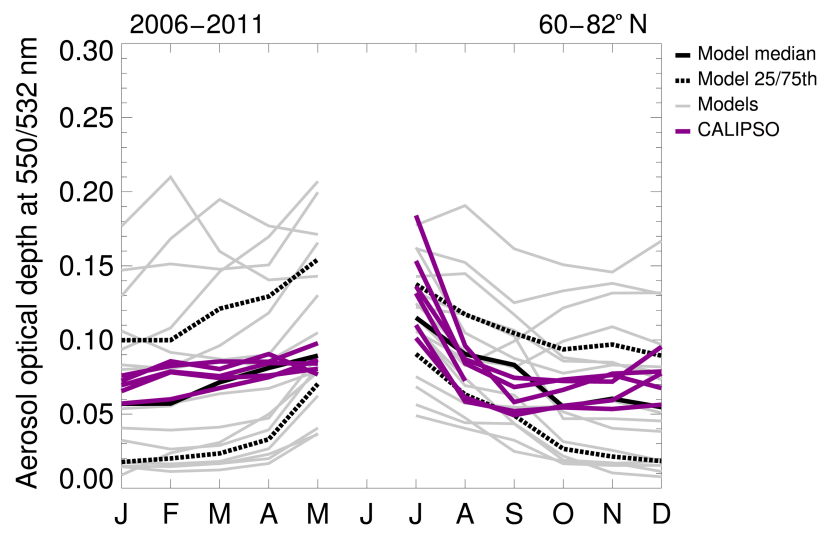

Figure 6. AOD in the Arctic $\left(60-82^{\circ} \mathrm{N}\right)$ from CALIPSO retrieval for the different years 2006-2011 (AOD532 nm) (purple lines) compared to the AeroCom Phase II models (thin grey lines) screened by CALIOP availability.

percentile and the maximum value, which is much higher than the corresponding values for sulfate. Note that all models have reported total AOD but not all the individual components' AOD; see Table 1. The AOD median and 25th/75th percentiles values are listed in Tables 3 and 4 .

Figure 9 shows the seasonal cycle of the AOD for the same individual components as in Fig. 8: sulfate, BC, OA, SOA, nitrate, sea-salt, and dust averaged over the Arctic region $\left(60-90^{\circ} \mathrm{N}\right)$. There is a large spread between the models. Most models show a peak in the AOD in summer, with a few models showing a late spring maximum. The geographical distribution over the same region for the summer and winter season is shown in Fig. 10. For sulfate the highest model-mean AOD values in summer are found in the Russian and northern Europe regions (0.09), while for BC the highest AOD values are found over Russia and eastern Asia (0.006). Both OAs and SOAs show a maximum in summer in the fire season with the highest AOD over Russia and eastern
Asia (0.07 and 0.02, respectively). Summer is also the season with maximum chemical production. In winter the AOD values are low for OAs and SOAs. There is one outlier for OAs, CAM4-Oslo, which has very high marine primary OA emissions, and is the only model that includes MSA in the primary organics emissions (Tsigaridis et al., 2014). The emissions of aerosols (per mass) are dominated by sea-salt and dust. Since these emissions are mostly interactive (a function of wind speed and soil moisture for dust), a large model diversity in AOD is not surprising. Sea-salt AOD is highest during the winter season, with a maximum over the North Atlantic region (0.1). The areas around the Norwegian Sea and Barents Sea have the highest cyclonic activity in winter (Serreze and Barrett, 2008). For dust aerosols, the models show a maximum in spring/early summer and a secondary maximum in September. The spring maximum originates most likely from dust storms in the Gobi and Taklamakan deserts, while the second smaller maximum in September might be due to local sources (Barrie and Barrie, 1990). GOCART shows higher AOD values for dust compared to the other models, probably linked to an overestimation of dust emissions (Kim et al., 2014). Only four models have reported AOD from nitrate. The nitrate maximum is located over Eurasia in winter and over eastern Asia in summer.

Figure 11 shows the seasonal cycle of AOD in the Antarctic for all the aerosol species. The model-median AOD has a maximum during the $\mathrm{SH}$ summer season of 0.02 and is reduced to about half during the winter season $(0.01)$. Modelled BC, sulfate, and dust concentrations are highest during the winter months (SH summer). GISS-modelE shows higher values for SOAs. This model has the highest SOA lifetime (14 days) because of a large amount of SOAs in the upper troposphere, where there is less scavenging and more SOA available to be transported poleward. SPRINTARS shows the opposite behaviour on the seasonal cycle of sulfate AOD compared to the other models. This is likely linked to an anomaly in the relative humidity over East Antarctica in the 

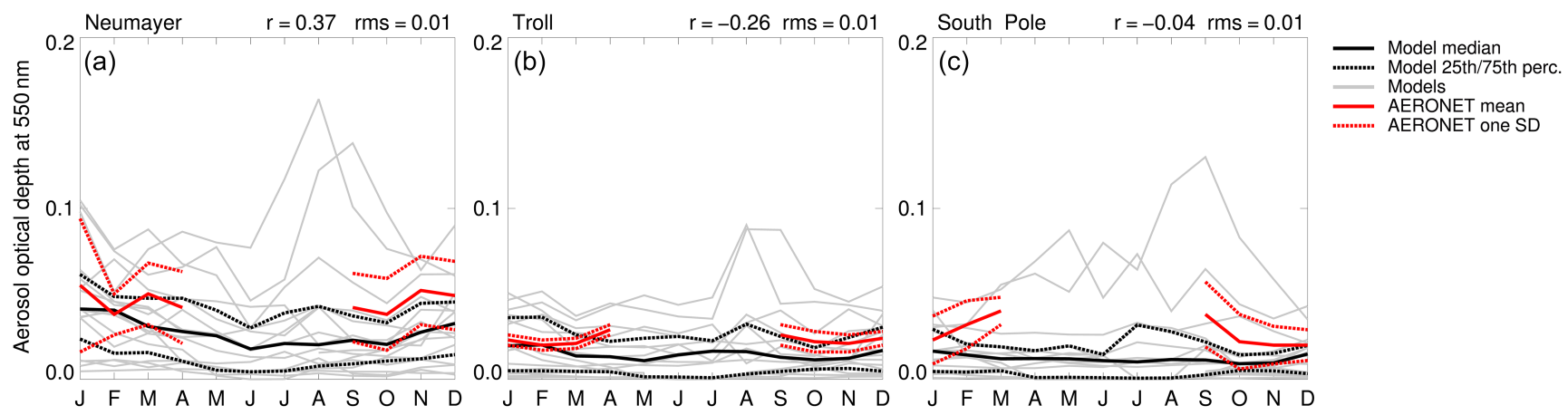

Figure 7. As Fig. 2, but for three Antarctic sites: Neumeyer $70^{\circ} \mathrm{S}, 8^{\circ} \mathrm{W}$ (a), Troll $72^{\circ} \mathrm{S}, 2^{\circ} \mathrm{E}(\mathbf{b})$, and South Pole $90^{\circ} \mathrm{S}, 0^{\circ} \mathrm{E}$ (c), with values from Tomasi et al. (2015).
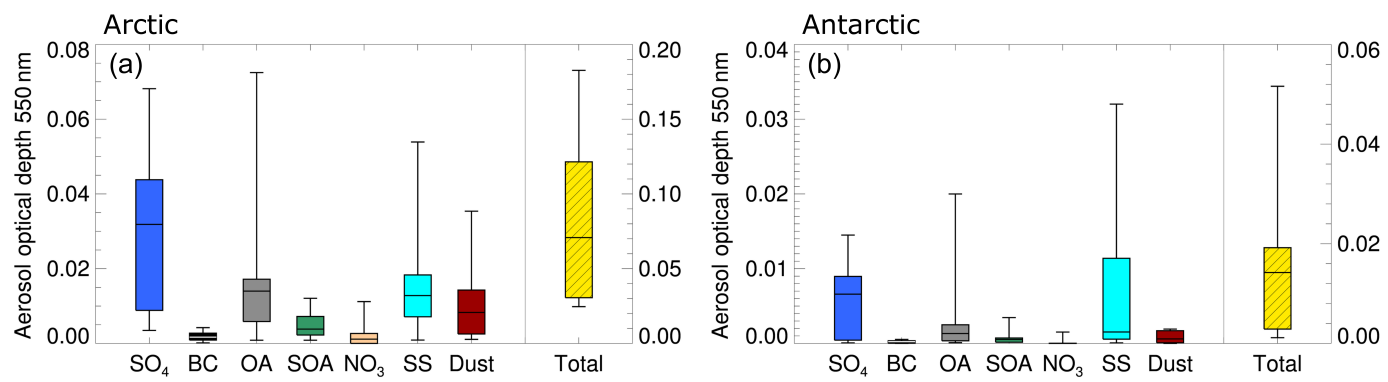

Figure 8. Annual mean multi-model median AOD for the individual components (sulfate, BC (from all sources), total OA (from all sources), SOA, nitrate, sea-salt, and dust) and the total aerosol, averaged over the Arctic $\left(60-90^{\circ} \mathrm{N}\right)$ (a) and the Antarctic $\left(70-90^{\circ} \mathrm{S}\right)(\mathbf{b})$. The bottom and top of each box are the first and third (25th/75th) quartiles, and the band inside the box is the model median. The whiskers represent the minimum and maximum of the model range. Note the different vertical axis - the right-hand vertical axis is for total AOD.
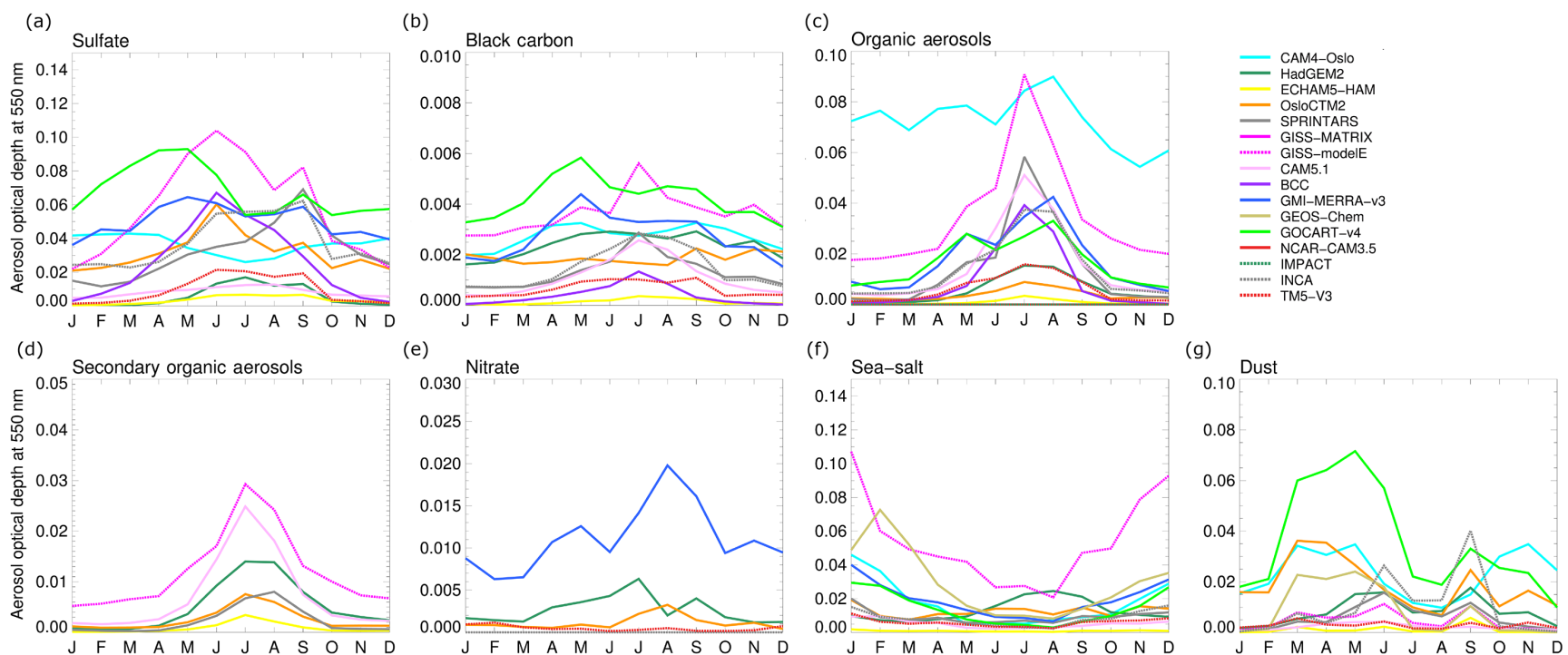

Figure 9. Seasonal cycle multi-model Arctic AOD for (a) sulfate, (b) BC (from all sources), (c) total OA (from all sources), (d) SOA, (e) nitrate, (f) sea-salt, and (g) dust. The Arctic region is defined as 60-90 ${ }^{\circ}$ N. Note the different axes. 
Table 3. Annual mean Arctic (60-90 $\mathrm{N})$ AOD AeroCom Phase II model median, model range (minimum and maximum), and the 25th/75th percentile. The number of models for each species is given in the rightmost column. BC is total BC from all sources and OA is total OA from all sources.

\begin{tabular}{lcccccr}
\hline & Median & Minimum & Maximum & 25th percentile & 75th percentile & Number of models \\
\hline Total & 0.071 & 0.025 & 0.183 & 0.031 & 0.121 & 16 \\
Sulfate & 0.032 & 0.003 & 0.068 & 0.009 & 0.044 & 12 \\
BC & 0.002 & 0.000 & 0.004 & 0.001 & 0.003 & 12 \\
OA & 0.014 & 0.001 & 0.072 & 0.006 & 0.017 & 11 \\
SOA & 0.004 & 0.001 & 0.012 & 0.002 & 0.007 & 6 \\
Nitrate & 0.001 & 0.000 & 0.011 & 0.000 & 0.003 & 4 \\
Sea-salt & 0.013 & 0.001 & 0.054 & 0.007 & 0.018 & 12 \\
Dust & 0.008 & 0.001 & 0.035 & 0.003 & 0.014 & 11 \\
\hline
\end{tabular}

Table 4. As Table 3, but averaged over the Antarctic region (70-90 S).

\begin{tabular}{lcccccr}
\hline & Median & Minimum & Maximum & 25th percentile & 75th percentile & Number of models \\
\hline Total & 0.014 & 0.001 & 0.052 & 0.003 & 0.019 & 16 \\
Sulfate & 0.007 & 0.000 & 0.014 & 0.000 & 0.009 & 12 \\
BC & 0.000 & 0.000 & 0.001 & 0.000 & 0.000 & 12 \\
OA & 0.001 & 0.000 & 0.020 & 0.000 & 0.002 & 11 \\
SOA & 0.001 & 0.000 & 0.003 & 0.000 & 0.001 & 6 \\
Nitrate & 0.000 & 0.000 & 0.002 & 0.000 & 0.000 & 4 \\
Sea-salt & 0.002 & 0.000 & 0.032 & 0.001 & 0.011 & 12 \\
Dust & 0.001 & 0.000 & 0.002 & 0.000 & 0.002 & 11 \\
\hline
\end{tabular}

Table 5. Annual mean Arctic $\left(60-90^{\circ} \mathrm{N}\right)$ DAE AeroCom Phase II model median, model range (minimum and maximum), and the 25th/75th percentile. The number of models for each species is given in the rightmost column. BC FF is BC from fossil fuel and biofuel emissions and $\mathrm{OA} F \mathrm{FF}$ is $\mathrm{OA}$ from fossil fuel and biofuel emissions. $\mathrm{BB}$ is $\mathrm{BC}$ and $\mathrm{AO}$ combined from biomass burning emissions.

\begin{tabular}{lrrrrrr}
\hline & Median & Minimum & Maximum & 25th percentile & 75th percentile & Number of models \\
\hline Total & -0.12 & -0.30 & 0.09 & -0.22 & 0.01 & 16 \\
Sulfate & -0.24 & -0.43 & 0.01 & -0.29 & -0.11 & 14 \\
BC FF & 0.19 & 0.03 & 0.37 & 0.12 & 0.26 & 14 \\
OA FF & 0.00 & -0.04 & 0.02 & -0.02 & 0.00 & 14 \\
BB & 0.01 & -0.06 & 0.04 & -0.02 & 0.02 & 13 \\
SOA & -0.01 & -0.12 & 0.01 & -0.02 & 0.00 & 5 \\
Nitrate & -0.03 & -0.09 & 0.00 & -0.06 & -0.01 & 6 \\
\hline
\end{tabular}

simulation and has been improved in a newer version of the model. The high sea-salt values in Geos-Chem have been linked to an overestimation of sea-salt under high-wind conditions at middle and high latitudes (Jaeglé et al., 2011). By adding a SST-dependent source function, the model bias was reduced from +64 to $+33 \%$ for cruise measurements and from +32 to $-5 \%$ for ground-based sites. GMI-MERRA shows higher nitrate AOD values compared to the other models and is probably linked to the inclusion of oceanic $\mathrm{NH}_{3}$ emissions (based on the GEIA emission inventory) in the model. The CMIP5 emission data set does not include $\mathrm{NH}_{3}$ oceanic emissions. For a first assessment of nitrate from multiple models compared with observations, see Bian et al. (2017). Nine models from the AeroCom Phase III ni- trate experiment show large diversity in their simulated nitrate concentrations, especially in remote regions. The authors link this spread to the involvement of nitrate in complicated chemistry and the concentrations of nitrate depending on accurate simulations of precursors $\left(\mathrm{NH}_{3}, \mathrm{HNO}_{3}\right.$, dust, and sea-salt).

\subsection{Aerosol direct radiative forcing}

The DAE is calculated as the difference between the reflected solar radiation at TOA between simulations with present-day (2000) and pre-industrial (1850) emissions of anthropogenic aerosols and precursors. Figure 12 shows the multi-model DAE for sulfate, BC FF (from fossil fuel and biofuel emis- 
Table 6. As Table 5, but averaged over the Antarctic region $\left(70-90^{\circ} \mathrm{S}\right)$.

\begin{tabular}{lrrrrrr}
\hline & Median & Minimum & Maximum & 25th percentile & 75th percentile & Number of models \\
\hline Total & 0.03 & 0.00 & 0.10 & 0.01 & 0.07 & 16 \\
Sulfate & 0.00 & -0.03 & 0.00 & -0.01 & 0.00 & 14 \\
BC FF & 0.02 & 0.00 & 0.09 & 0.01 & 0.04 & 14 \\
OA FF & 0.00 & 0.00 & 0.01 & 0.00 & 0.00 & 14 \\
BB & 0.01 & -0.01 & 0.08 & 0.00 & 0.02 & 13 \\
SOA & 0.00 & 0.00 & 0.01 & 0.00 & 0.00 & 5 \\
Nitrate & 0.00 & 0.00 & 0.03 & 0.00 & 0.00 & 6 \\
\hline
\end{tabular}

(a) Sulfate
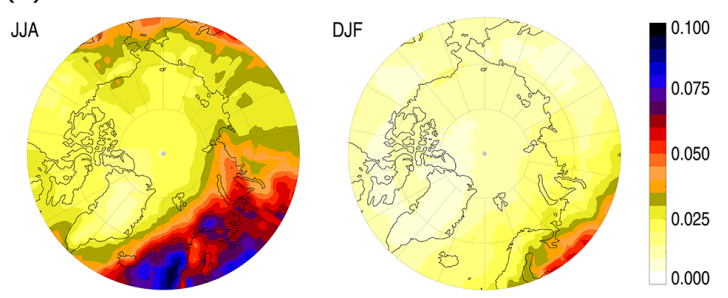

(b) Black carbon

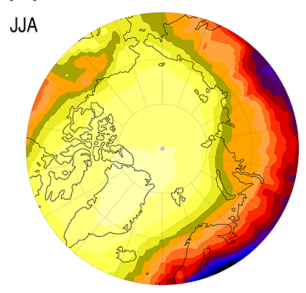

DJF
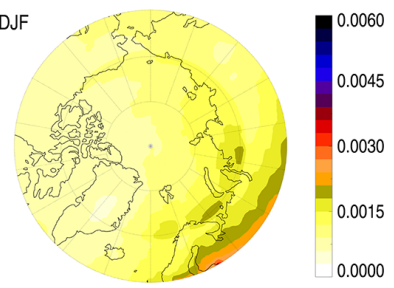

(c) Organic aerosols
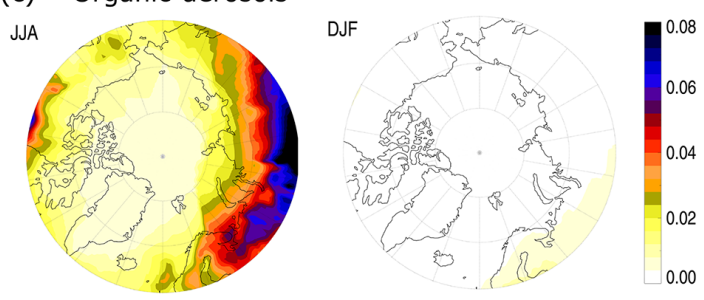

(d) Secondary organic aerosols
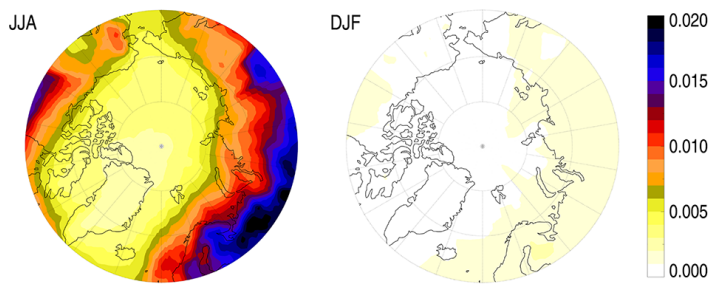

(e) Nitrate
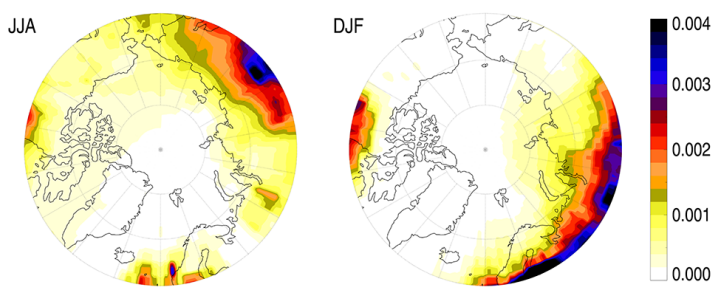

(f)

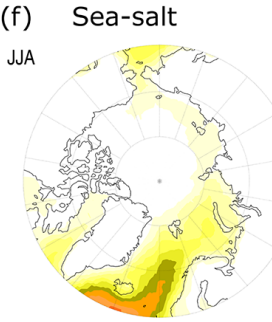

DJF
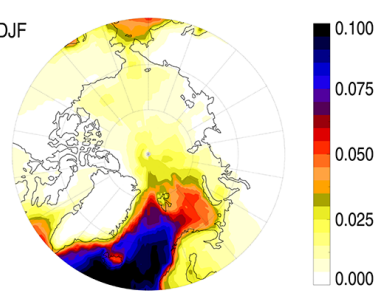

(g) Dust
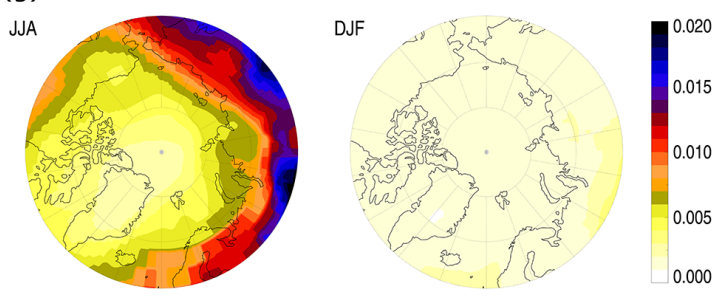

Figure 10. The geographical distributed model-median Arctic AOD (a) sulfate, (b) BC (from all sources), (c) total OA (from all sources), (d) SOA, (e) nitrate, (f) sea-salt, and (g) dust, for the summer (JJA) season (left) and the winter (DJF) season (right). Note the different axes.

sions), OA FF (from fossil fuel and biofuel emissions), BB, SOA, nitrate, and the total, averaged in the Arctic and the Antarctic regions. In the Arctic, the dominant aerosol forcing agents are $\mathrm{BC} \mathrm{FF}$ and sulfate with model-median DAE estimated at +0.19 and $-0.24 \mathrm{~W} \mathrm{~m}^{-2}$, respectively, although the Arctic AOD of BC is low compared to the other aerosols (Fig. 8). The other treated species are relatively low both in burden and in modelled DAE. The Arctic annual mean multimodel-median DAE is $-0.12 \mathrm{~W} \mathrm{~m}^{-2}$ (with the $25 \mathrm{th}, 75$ th percentile; $-0.22,0.01)$. The Antarctic model-median DAE 

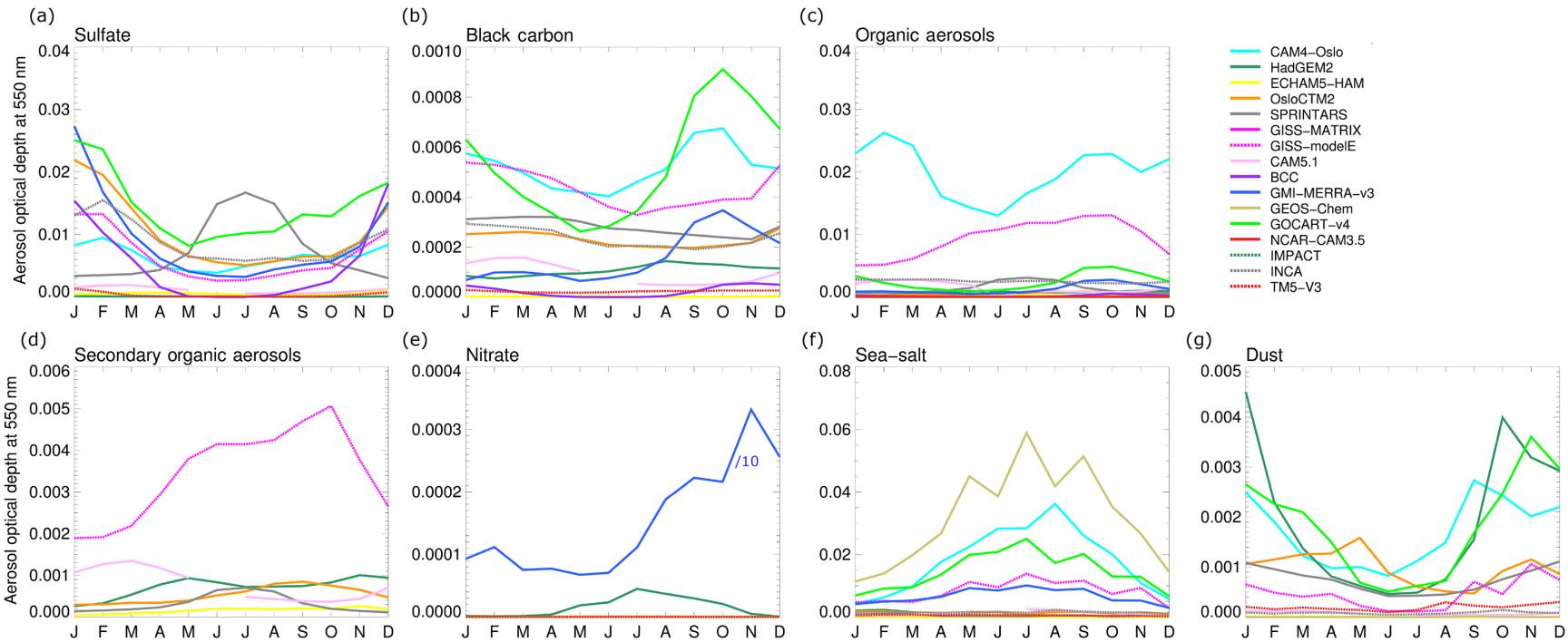

Figure 11. Multi-model seasonal cycle Antarctic mean (70-90 $\mathrm{S}$ ) AOD for the individual components (a) sulfate, (b) BC (from all sources), (c) total OA (from all sources), (d) SOA, (e) nitrate, (f) sea-salt, and (g) dust. Note the different axes.
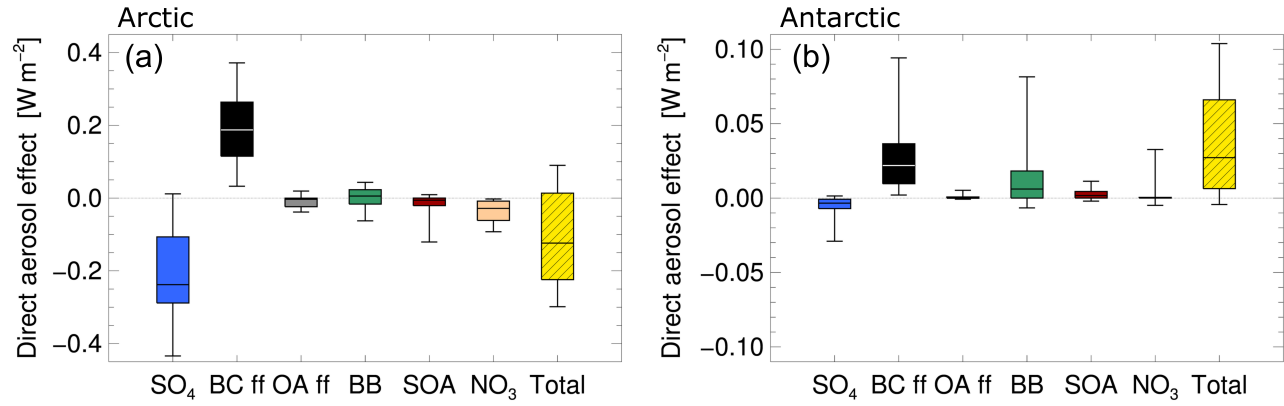

Figure 12. Annual mean multi-model DAE (in $\left.\mathrm{W} \mathrm{m}^{-2}\right)$ averaged over the Arctic $\left(60-90^{\circ} \mathrm{N}\right)$ (a) and the Antarctic $\left(70-90^{\circ} \mathrm{S}\right)(\mathbf{b})$ for the individual components (sulfate, BC FF, OA FF, BB, SOA, and nitrate) and the total aerosol. The bottom and top of each box are the first and third (25th/75th) quartiles, and the band inside the box is the model median. The whiskers represent the minimum and maximum of the model range. Note the different vertical axis.

is $0.03 \mathrm{~W} \mathrm{~m}^{-2}(0.01,0.07)$. The two largest forcing components here are BC FF and BB. Note that only the direct radiative forcing is reported. The numbers are listed in Tables 5 and 6.

Figure 13 shows the Arctic DAE seasonal cycle. The direct influence of aerosols on the radiation budget in the Arctic shifts from a BC-driven positive DAE during the spring months, to a sulfate-driven negative forcing in late summer, caused by higher surface albedo from sea-ice and snow in the former season (Ødemark et al., 2012). Also shown in Fig. 13 is the geographical distribution of DAE in summer (JJA), and a balance between sulfate and BC FF is also apparent here linked to albedo. Negative DAE from sulfate dominates land areas outside the high Arctic, while higher positive DAE from $\mathrm{BC} F F$ is evident in the high Arctic and in the Pacific.

Even though the AOD of BC is low in the Arctic, the DAE from BC FF dominates the total DAE in spring. In Fig. 14 we have normalized the JJA DAE (for total, sulfate, and BC FF) to AOD (total, sulfate and BC) to illustrate this. The total normalized forcing is positive in the high Arctic due to the high efficiency of the BC forcing. Outside the high Arctic, there is a band of negative direct forcing due to sulfate.

\subsection{Sensitivity simulations with GISS modelE}

The model-spread for aerosols at the poles is large and not entirely surprising, given the large sensitivity to remote transport for aerosol concentrations at high latitudes. The reasons for this spread include transport and removal mechanisms and the interaction between them. To illustrate some of the variation we have performed sensitivity tests with one of the AeroCom models, GISS modelE. The anthropogenic $\mathrm{BC}$ emissions (from fossil fuel and biofuel) have been doubled in southern Asia, eastern Asia, and Russia, and Fig. 18a shows the resulting (total) $\mathrm{BC}$ AOD in the Arctic for the 


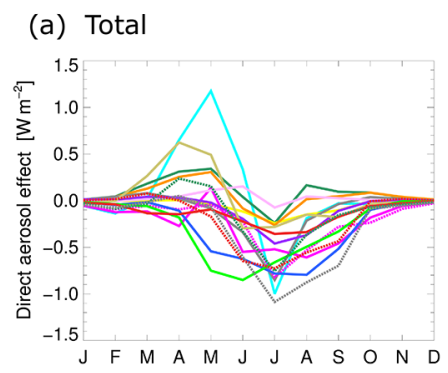

(b) Sulfate

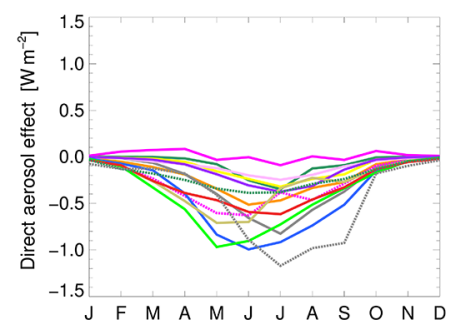

(d) Organic aerosols FF
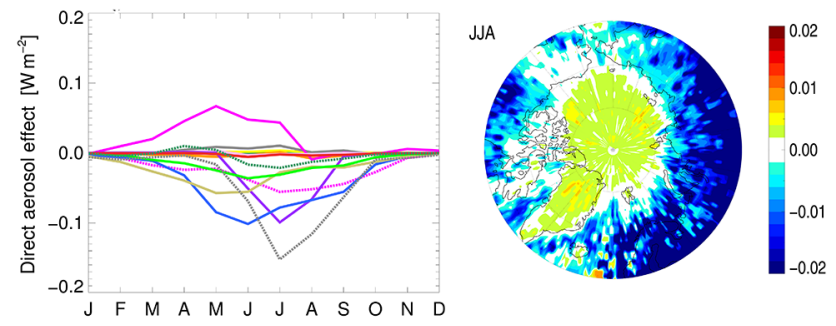

(f) Secondary organic aerosols
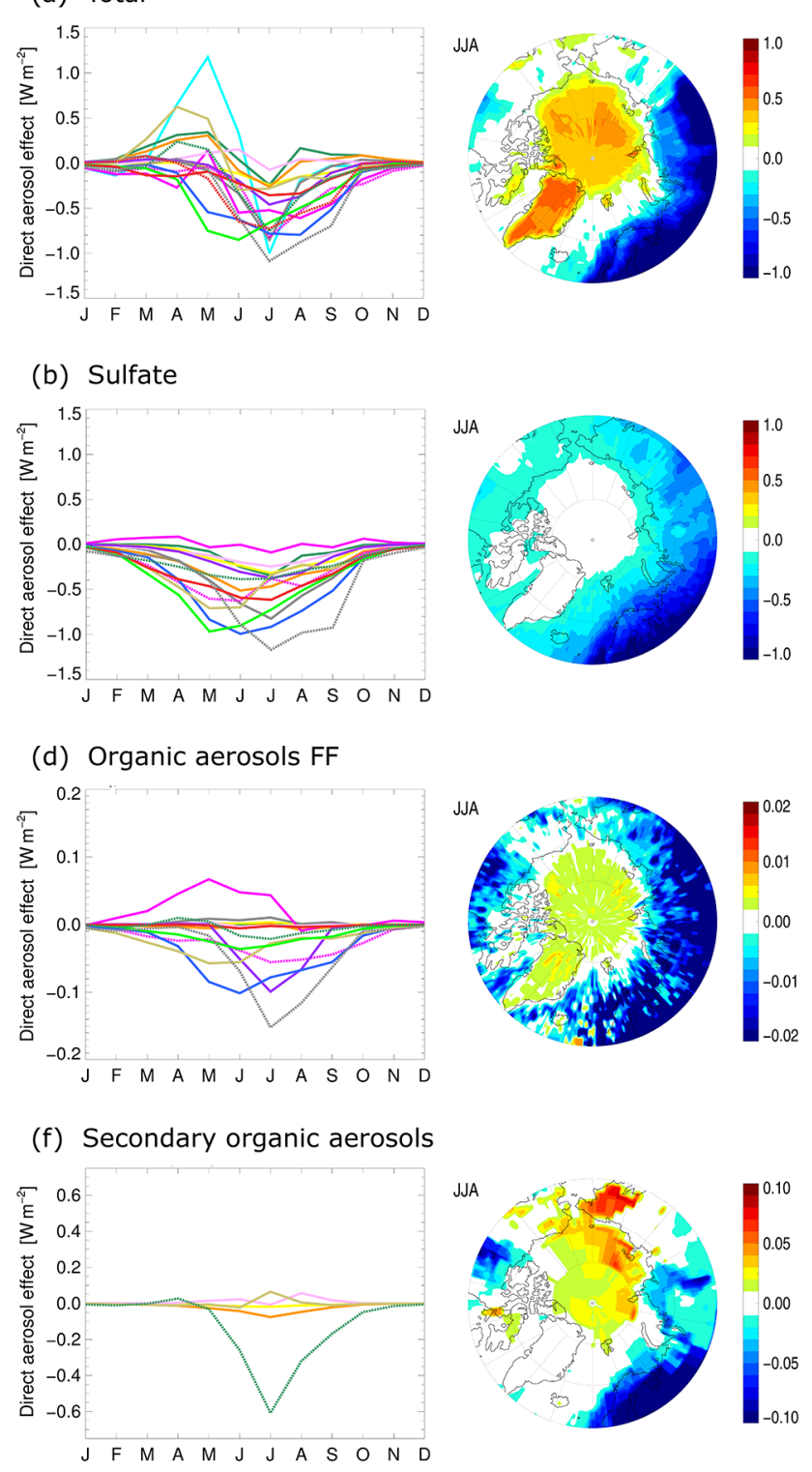
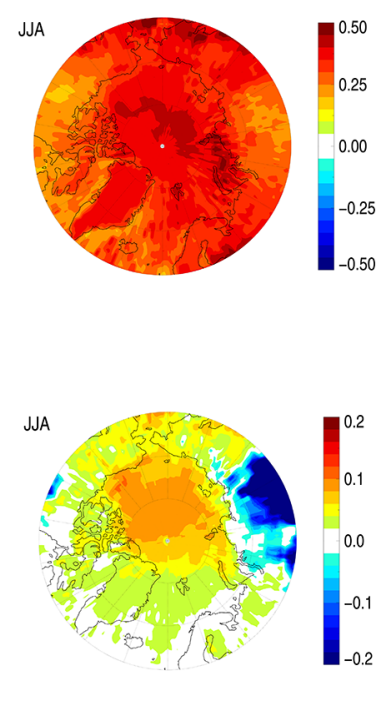

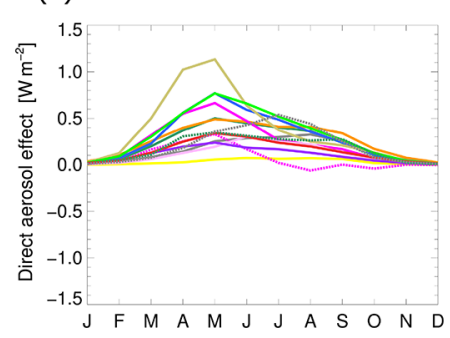

(e) Biomass burning

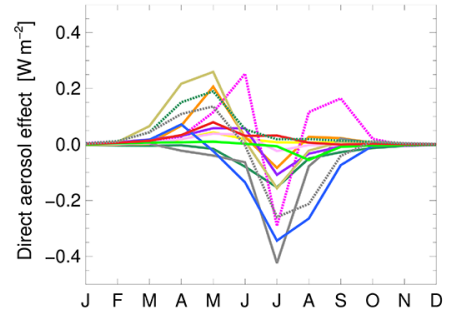

(g) Nitrate
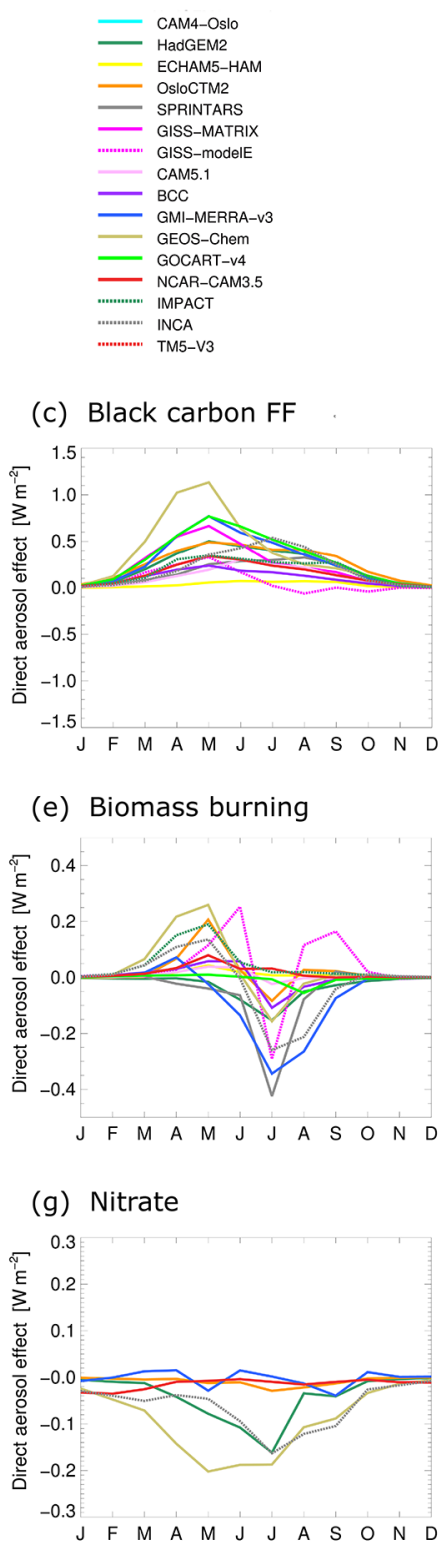

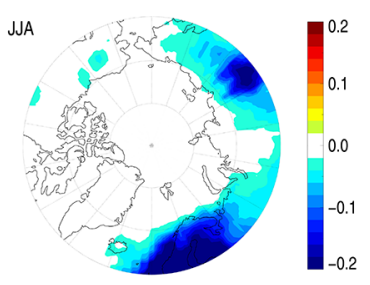

Figure 13. Arctic mean DAE seasonal cycle and the summer (JJA) mean model-media n geographical distribution of (a) total aerosol, (b) sulfate, (c) BC FF, (d) OA FF, (e) BB, (f) SOA, and (g) nitrate. Note the different axes.

(a) Total

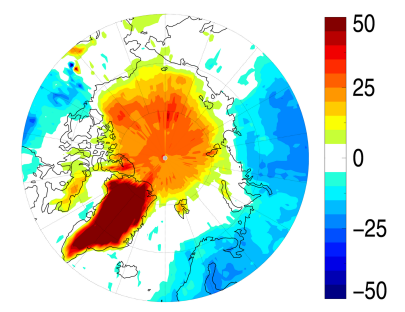

(b) Sulfate

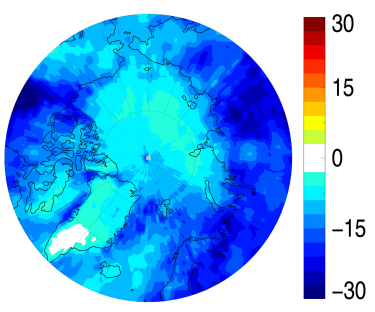

(c) Black carbon

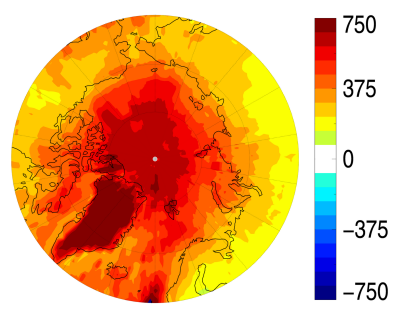

Figure 14. JJA mean model-median normalized DAE, i.e. total DAE (in $\mathrm{W} \mathrm{m}^{-2}$ ) per total AOD (a), sulfate DAE per sulfate AOD (b), and BC FF DAE per BC AOD (c). Note the different axes. 
(a) DAE total

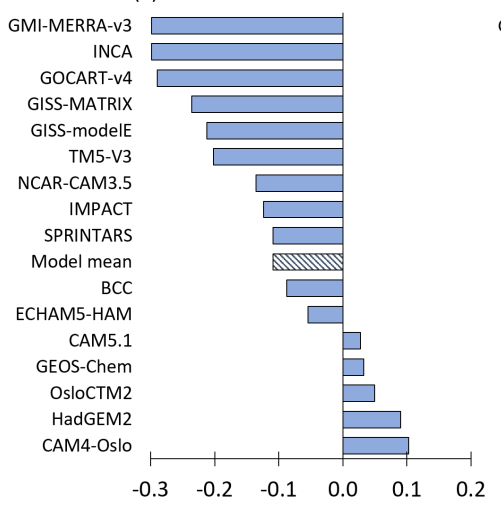

(b) DAE sulfate

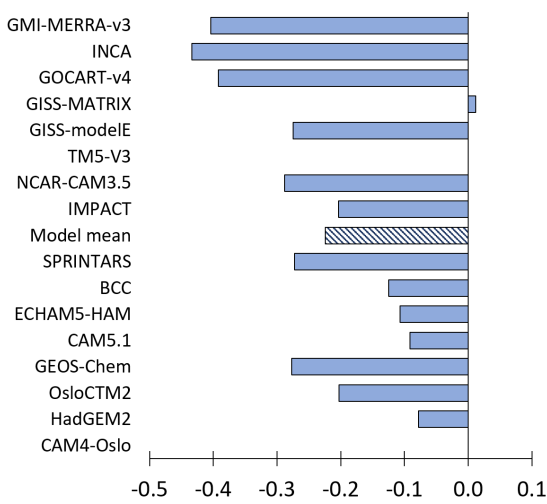

(c) DAE BC FF

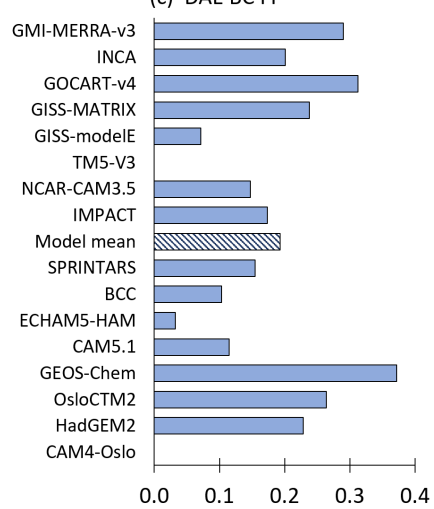

Figure 15. Arctic annual mean DAE (in $\mathrm{W} \mathrm{m}^{-2}$ ) for the AeroCom Phase II models, total (a), sulfate (b), BC FF (c). The striped bar is the model mean. TM5-V3 and CM4-Oslo have reported the total only.

(a) Total DAE per AOD

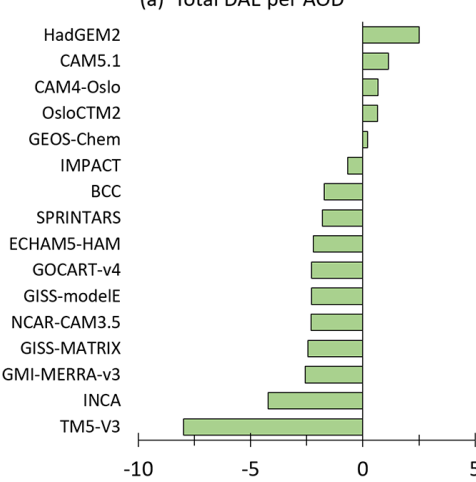

(b) $\mathrm{SO}_{4} \mathrm{DAE}$ per $\mathrm{SO}_{4} \mathrm{AOD}$

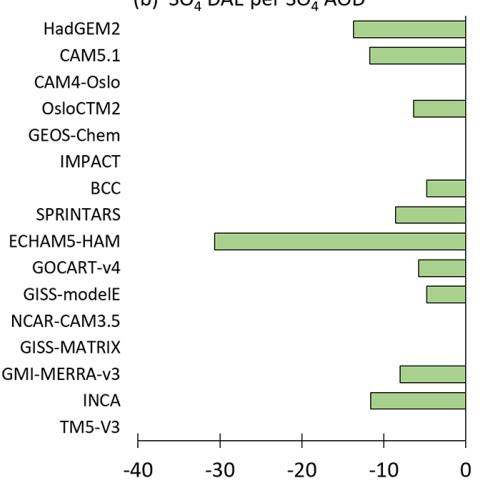

(c) BC FF DAE per BC AOD

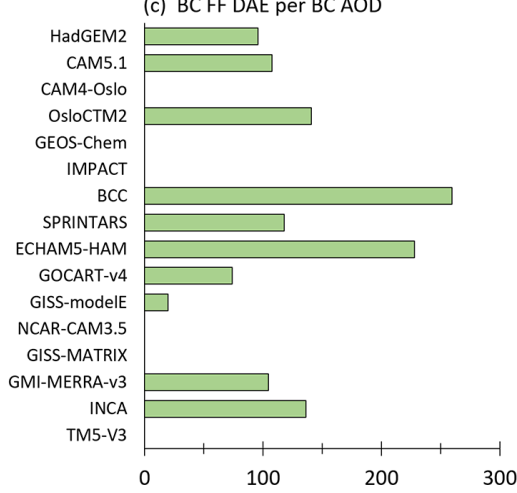

Figure 16. Arctic annual mean DAE per AOD for all AeroCom Phase II models, total (a), sulfate (b), and BC FF (c). Values for sulfate and BC are missing for GEOS-Chem, IMPACT, NCAR-CAM3.5, GISS-MATRIX, CAM4-Oslo and TM5 (see Table 1).

different regional emission perturbations. The annual mean $\mathrm{BC}$ AOD in the Arctic increases by $33 \%$ from a doubling of the BC FF emissions in East Asia, while doubling in southern Asia and Russia increase the BC AOD by 10 and $8 \%$, respectively. The change in AOD from a doubling in emissions is still within the AeroCom model range, shown in grey lines. Here we only show plots for the Arctic, but the increase in BC AOD in Antarctica is not negligible: $28 \%$ increase for a doubling in eastern Asia and $7 \%$ for a doubling in southern Asia (zero for Russia) (Fig. S2). We have also tested the sensitivity to the $e$-folding time of $\mathrm{BC}$ from hydrophobic (fresh) to hydrophilic (aged) state. GISS modelE has a BC global lifetime of 5.9 days, which is close to the AeroCom average global lifetime of 6.5 days (it ranges from 3.8 days in CAM5.1 to 17.1 days in HadGEM2) (Samset et al., 2014). Figure $18 \mathrm{~b}$ shows the resulting change in BC AOD in Arctic by (1) doubling the $e$-folding time and (2) reducing it by $50 \%$. By reducing the $e$-folding time by half, $\mathrm{BC}$ decreases by $30 \%$ at both poles. However, by making the lifetime longer by doubling the $e$-folding time, the BC AOD increases with $36-39 \%$ at both poles. The change in $\mathrm{BC}$ is still within the AeroCom model range.

Figure 15 shows the multi-model DAE in the Arctic, sorted by highest-to-lowest, for total aerosol and for sulfate and BC FF. Most models have an annual mean negative net DAE in the Arctic, ranging from -0.3 to $0.0 \mathrm{~W} \mathrm{~m}^{-2}$, while five models show a positive net DAE (CAM4-Oslo, HadGEM2, OsloCTM2, GEOS-Chem, and CAM5.1). These latter models have a lower-than-average negative sulfate forcing (HadGEM2, CAM5.1, OsloCTM2), and/or higher-than-average positive BC FF forcing (GEOSChem, OsloCTM2, and HadGEM2). When normalizing the Arctic DAE with AOD for each model (Fig. 16), it is apparent that some models have a high forcing efficiency for sulfate (ECHAM5-HAM2) and/or BC FF (BCC, ECHAM5HAM2).

Figure 17 shows the seasonal cycle of DAE for total aerosols and for sulfate, $\mathrm{BC} \mathrm{FF}, \mathrm{OA} \mathrm{FF}, \mathrm{BB}, \mathrm{SOA}$, and nitrate in Antarctica. There is a large spread in DAE during $\mathrm{SH}$ summer season, with values ranging from 0 to $0.3 \mathrm{~W} \mathrm{~m}^{-2}$, dominated by BC DAE. Several of the models that have the 

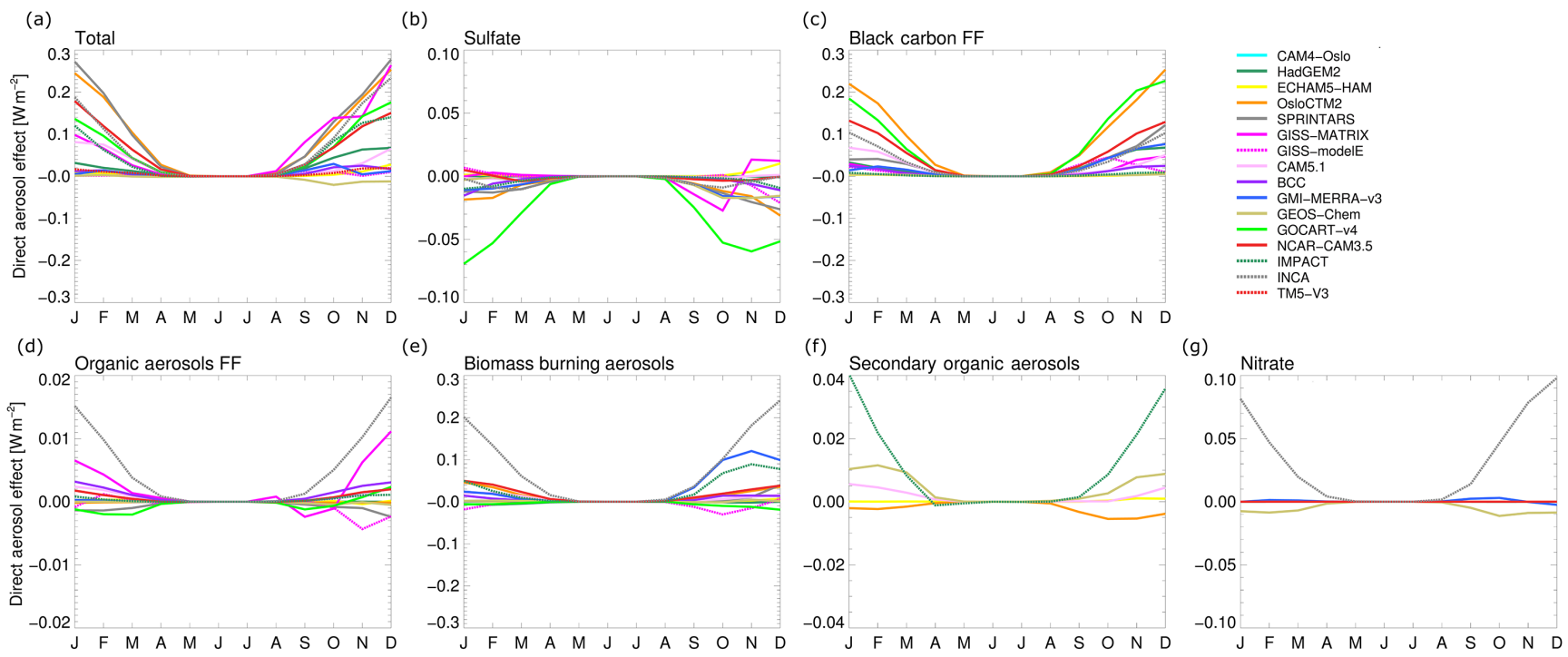

Figure 17. Antarctic mean $\left(70-90^{\circ} \mathrm{S}\right)$ seasonal cycle of (a) the total DAE and the DAE for (b) sulfate, (c) BC FF, (d) OA FF, (e) BB, (f) SOA, and (g) nitrate. Note the different axes.

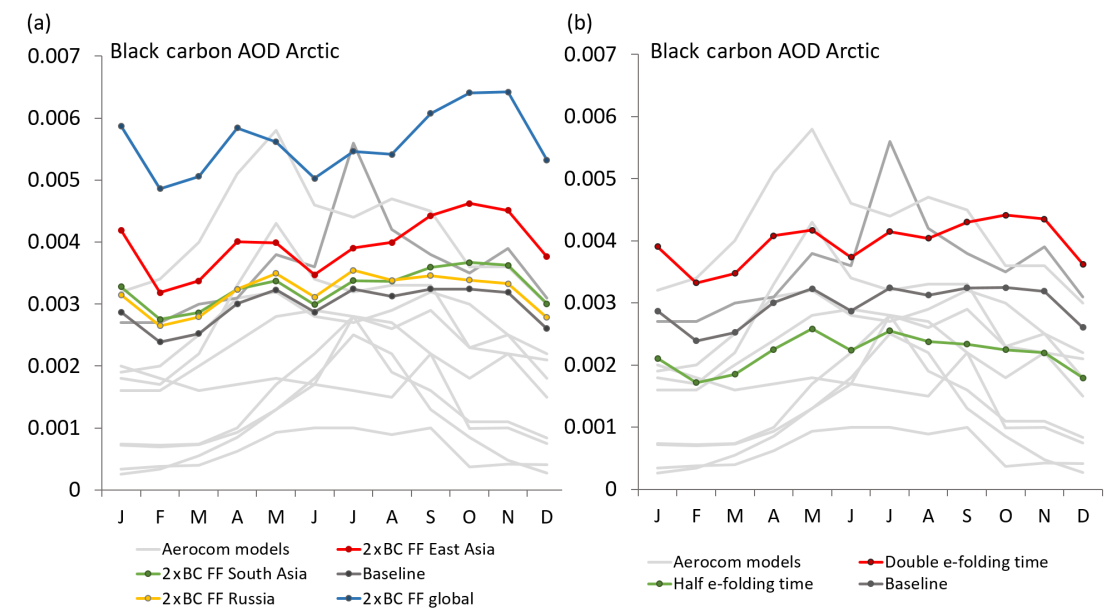

Figure 18. Arctic mean seasonal cycle of (total) BC AOD for simulations with GISS modelE (in colours) compared to the AeroCom models (in light grey). Panel (a) shows the experiment with doubling the emissions, while panel (b) shows the effect of changing the $e$-folding lifetime. The darker grey AeroCom model is the GISS modelE AeroCom run. Panel (a) shows emission perturbations for a doubling of BC emissions (fossil fuel and biofuel) in southern Asia (green), eastern Asia (red), Russia (yellow), and global (blue). Panel (b) shows double (red) and half (green) of the $e$-folding time from hydrophobic to hydrophilic $\mathrm{BC}$.

highest (positive) BC FF DAE also have the highest (negative) sulfate DAE, as indicated by Myhre et al. (2013). As these models do not show particularly strong forcing per unit AOD (see e.g. Fig. 16), but generally have high values for Antarctic AOD (Fig. 11), we attribute this correlation to efficient transport of aerosols to the South Pole region.

\section{Summary and discussion}

We have reported on modelled AOD and DAE at both poles, and compared individual and multi-model results to avail- able measurements. Defining the Arctic as the $60-90^{\circ} \mathrm{N}$ region, the dominant aerosol species, in terms of AOD, are sulfate, sea-salt, and OA. The total model-median AOD is 0.07, which is close to observed AOD. However, the intermodel spread is very wide (0.02-0.18). Compared to measurements at nine Arctic stations, most models tend to underestimate the AOD, especially the build-up of aerosols in early winter and spring. Seasonally, the influence of aerosols on the Arctic energy balance shifts from a BC-driven positive DAE during the spring months, to a sulfate-driven negative DAE in late summer. Despite a relatively low Arctic BC AOD compared 
to the other aerosols, the BC FF DAE dominates in spring with an annual mean model median of $0.19 \mathrm{~W} \mathrm{~m}^{-2}(0.12$, $0.26 \mathrm{~W} \mathrm{~m}^{-2} 25 \mathrm{th} / 75$ th percentiles). The total Arctic annual mean DAE model median is slightly negative, $-0.12 \mathrm{~W} \mathrm{~m}^{-2}$ $(-0.22,0.01)$. We note, however, that this estimate of Arctic aerosol radiative forcing does not include semi- or indirect cloud effects, or surface albedo modification. The Arctic surface radiative forcing from $\mathrm{BC}$ in snow has been estimated at $0.18 \mathrm{~W} \mathrm{~m}^{-2}$ using deposited fields from the AeroCom Phase II models into an offline land and sea-ice model (Jiao et al., 2014). There are few estimates of the semi-direct effects of aerosols, which is mostly due to BC. Bond et al. (2013) indicates a $-0.1 \mathrm{~W} \mathrm{~m}^{-2}$ global effect, equally split between direct and indirect effects, while a later study also indicates that the semi-direct effect counteracts about $50 \%$ of the direct effect, independent of altitude (Samset and Myhre, 2015). None of these estimates are made specifically for the Arctic. Indirect cloud effects are likely different in the Arctic than at lower latitudes, in large part because of the already bright surfaces in the Arctic. Also, cloud emissivity might be more important here, as thermal radiation dominates the dark winter months (Garrett et al., 2004).

The models also predict a fair amount of aerosol transport to the Antarctic region (defined here as $70-90^{\circ} \mathrm{S}$ ). In Antarctica, modelled AOD is smaller in magnitude than in the Arctic, with an annual mean of 0.01 (0.001-0.05 model range). Compared to limited available measurements, these values might be on the lower end of the spectrum. As in the Arctic, the dominant aerosol species is sulfate. The dominant aerosol forcing agent in the Antarctic, however, is BC, resulting in a small, but positive DAE in this region $\left(0.03 \mathrm{~W} \mathrm{~m}^{-2}\right)$. Again, this does not include possible additional effects of surface albedo modification (Jiao et al., 2014).

Not surprisingly, the spread in modelled AOD at both poles is large. The relative spread in DAE is larger than the relative spread in AOD, linked to each model's radiation parameterization (Stier et al., 2013). Sensitivity experiments of $\mathrm{BC}$ with one of the AeroCom models reveal that the Arctic $\mathrm{BC}$ AOD is sensitive to the emissions and lifetime of BC. A doubling of fossil fuel and biofuel emissions in eastern Asia results in a $33 \%$ increase in Arctic BC AOD. However, radical changes such as reducing the $e$-folding lifetime by half or doubling it, still fall within the AeroCom model range.

The AeroCom data are only available as monthly averages, and we have therefore compared them with monthly averaged retrievals from AERONET and CALIOP/MODIS. Schutgens et al. (2016a, b) suggests that models should be temporally collocated to the observations before comparing the data to prevent sampling errors. In their study three global models were compared to AERONET/MODIS and sampling errors up to $100 \%$ in AOD were apparent for yearly and monthly averages. Since the AeroCom data are only provided monthly, this is a potential problem both for this and most other AeroCom studies.
Various factors lie behind the large spread in modelled AOD in the polar regions. Recommendations to improve our understanding of the role of aerosols in the polar regions and to reduce the uncertainties include sensitivity tests on removal processes (Wang et al., 2013; Liu et al., 2011; Bourgeois and Bey, 2011) and resolution (Ma et al., 2014) during transport to the Arctic, up to date treatment of aerosol mixtures and missing emission sources (Stohl et al., 2013; Evangeliou et al., 2016), and a better characterization of measurement uncertainties in satellite data over polar land and oceans. Of these, updated emission inventories (global and polar) and model validation of AODs and column loadings against local observations seem most crucial for providing a solid baseline for evaluations of transport schemes and calculations of radiative forcing, taking into account a broader range of physical effects.

Data availability. AeroCom data and CALIOP data are available through http://aerocom.met.no. Sensitivity studies and further analysis results are available upon request to Maria Sand. AERONET data are available at http://aeronet.gsfc.nasa.gov/.

\section{The Supplement related to this article is available online at https://doi.org/10.5194/acp-17-12197-2017- supplement.}

Acknowledgements. Maria Sand has received funding from The Research Council of Norway (RCN) through a FRIPRO Mobility Grant, BlackArc, contract no 240921. The FRIPRO Mobility grant scheme (FRICON) is co-funded by the European Union's Seventh Framework Programme for research, technological development and demonstration under Marie Curie grant agreement no 608695. Maria Sand and Bjørn H. Samset were funded through the Polish-Norwegian Research Programme project iAREA, and RCN projects AEROCOM-P3 and AC/BC (240372). Richard C. Easter and Steven J. Ghan were supported by the US Department of Energy Office of Science Decadal and Regional Climate Prediction using Earth System Models (EaSM) programme. The Pacific Northwest National Laboratory is operated for the DOE by Battelle Memorial Institute under contract DE-AC06-76RLO 1830. Guangxing Lin and Joyce E. Penner were supported by the National Science Foundation (projects AGS-0946739 and ARC-1023387) and the Department of Energy (DOE FG02 01 ER63248 and DOE DE-SC0008486. Toshihiko Takemura is supported by the NEC SX-ACE supercomputer system of the National Institute for Environmental Studies, Japan, the Environmental Research and Technology Development Fund (S-12-3) of the Ministry of Environment, Japan and JSPS KAKENHI Grant Numbers JP15H01728 and JP15K12190. Trond Iversen, Alf Kirkevåg and Øyvind Seland were supported by the Norwegian Research Council through the projects EVA (grant 229771), EarthClim (207711/E10), NOTUR (nn2345k), and NorStore (ns2345k), and through the EU projects PEGASOS and ACCESS and Nordforsk-CRAICC. Philip Stier acknowledges funding from the European Research Council (ERC) under the European Union's Seventh Framework Programme 
(FP7/2007-2013) ERC project ACCLAIM (Grant Agreement FP7-280025) and from the UK Natural Environment Research Council project GASSP (grant number NE/J022624/1). The CESM project is supported by the National Science Foundation and the Office of Science (BER) of the US Department of Energy. NCAR is sponsored by the National Science Foundation. CALIPSO is a joint satellite mission between NASA and the French Agency, CNES. Guangxing Lin and Fangqun $\mathrm{Yu}$ were supported by the National Aeronautics and Space Administration (NASA NNX17AG35G) and the National Science Foundation (NSF AGS-1550816). We thank the PI investigators and their staff for establishing and maintaining the AERONET sites used in this study.

Edited by: Maria Kanakidou

Reviewed by: two anonymous referees

\section{References}

Albrecht, B. A.: Aerosols, cloud microphysics, and fractional cloudiness, Science, 245, 1227-1230, 1989.

AMAP: The Impact of Black Carbon on Arctic Climate, Arctic Monitoring and Assessment Programme (AMAP), Oslo, Norway, p. 70, 2011.

Arimoto, R., Hogan, A., Grube, P., Davis, D., Webb, J., Schloesslin, C., Sage, S., and Raccah, F.: Major ions and radionuclides in aerosol particles from the South Pole during ISCAT-2000, Atmos. Environ., 38, 5473-5484, https://doi.org/10.1016/j.atmosenv.2004.01.049, 2004.

Barrie, L. A. and Barrie, M. J.: Chemical components of lower tropospheric aerosols in the high Arctic: Six years of observation, J. Atmos. Chem., 11, 211-226, 1990.

Bauer, S. E., Wright, D. L., Koch, D., Lewis, E. R., McGraw, R., Chang, L.-S., Schwartz, S. E., and Ruedy, R.: MATRIX (Multiconfiguration Aerosol TRacker of mIXing state): an aerosol microphysical module for global atmospheric models, Atmos. Chem. Phys., 8, 6003-6035, https://doi.org/10.5194/acp-8-60032008, 2008.

Bellouin, N., Rae, J., Jones, A., Johnson, C., Haywood, J., and Boucher, O.: Aerosol forcing in the Climate Model Intercomparison Project (CMIP5) simulations by HadGEM2-ES and the role of ammonium nitrate, J. Geophys. Res., 116, D20206, https://doi.org/10.1029/2011JD016074, 2011.

Bian, H., Chin, M., Rodriguez, J. M., Yu, H., Penner, J. E., and Strahan, S.: Sensitivity of aerosol optical thickness and aerosol direct radiative effect to relative humidity, Atmos. Chem. Phys., 9, 2375-2386, https://doi.org/10.5194/acp-9-2375-2009, 2009.

Bian, H., Chin, M., Hauglustaine, D. A., Schulz, M., Myhre, G., Bauer, S. E., Lund, M. T., Karydis, V. A., Kucsera, T. L., Pan, X., Pozzer, A., Skeie, R. B., Steenrod, S. D., Sudo, K., Tsigaridis, K., Tsimpidi, A. P., and Tsyro, S. G.: Investigation of global nitrate from the AeroCom Phase III experiment, Atmos. Chem. Phys. Discuss., https://doi.org/10.5194/acp-2017-359, in review, 2017.

Bigg, E. K.: Comparison of Aerosol at Four Baseline Atmospheric Monitoring Stations, J. Appl. Meteorol., 19, 521-533, https://doi.org/10.1175/15200450(1980)019<0521:COAAFB>2.0.CO;2, 1980.

Bond, T. C., Doherty, S. J., Fahey, D. W., Forster, P. M., Berntsen, T., DeAngelo, B. J., Flanner, M. G., Ghan, S.,
Kärcher, B., Koch, D., Kinne, S., Kondo, Y., Quinn, P. K., Sarofim, M. C., Schultz, M. G., Schulz, M., Venkataraman, C., Zhang, H., Zhang, S., Bellouin, N., Guttikunda, S. K., Hopke, P. K., Jacobson, M. Z., Kaiser, J. W., Klimont, Z., Lohmann, U., Schwarz, J. P., Shindell, D., Storelvmo, T., Warren, S. G., and Zender, C. S.: Bounding the role of black carbon in the climate system: A scientific assessment, J. Geophys. Res.Atmos., 18, 5380-5552, https://doi.org/10.1002/jgrd.50171, 2013.

Boucher, O., Randall, D., Artaxo, P., Bretherton, C., Feingold, G., Forster, P., Kerminen, V.-M., Kondo, Y., Liao, H., Lohmann, U., Rasch, P., Satheesh, S. K., Sherwood, S., Stevens, B., and Zhang, X. Y.: Clouds and aerosols, in: Climate Change 2013: The Physical Science Basis. Contribution of Working Group I to the Fifth Assessment Report of the Intergovernmental Panel on Climate Change, edited by: Stocker, T. F., Qin, D., Plattner, G.K., Tignor, M., Allen, S. K., Boschung, J., Nauels, A., Xia, Y., Bex, V., and Midgley, P. M., Cambridge University Press, Cambridge, UK and New York, NY, USA, pp. 571-657, 2013.

Bourgeois, Q. and Bey, I.: Pollution transport efficiency toward the Arctic: Sensitivity to aerosol scavenging and source regions, J. Geophys. Res., 116, D08213, https://doi.org/10.1029/2010JD015096, 2011.

Browse, J., Carslaw, K. S., Mann, G. W., Birch, C. E., Arnold, S. R., and Leck, C.: The complex response of Arctic aerosol to sea-ice retreat, Atmos. Chem. Phys., 14, 7543-7557, https://doi.org/10.5194/acp-14-7543-2014, 2014.

Clarke, A. D. and Noone, K. J.: Soot in the Arctic snowpack: a cause for perturbations in radiative transfer, Atmos. Environ., 19, 2045-2053, https://doi.org/10.1016/0004-6981(85)90113-1, 1985.

Eckhardt, S., Quennehen, B., Olivié, D. J. L., Berntsen, T. K., Cherian, R., Christensen, J. H., Collins, W., Crepinsek, S., Daskalakis, N., Flanner, M., Herber, A., Heyes, C., Hodnebrog, Ø., Huang, L., Kanakidou, M., Klimont, Z., Langner, J., Law, K. S., Lund, M. T., Mahmood, R., Massling, A., Myriokefalitakis, S., Nielsen, I. E., Nøjgaard, J. K., Quaas, J., Quinn, P. K., Raut, J.-C., Rumbold, S. T., Schulz, M., Sharma, S., Skeie, R. B., Skov, H., Uttal, T., von Salzen, K., and Stohl, A.: Current model capabilities for simulating black carbon and sulfate concentrations in the Arctic atmosphere: a multi-model evaluation using a comprehensive measurement data set, Atmos. Chem. Phys., 15, 9413-9433, https://doi.org/10.5194/acp-15-9413-2015, 2015.

Evangeliou, N., Balkanski, Y., Hao, W. M., Petkov, A., Silverstein, R. P., Corley, R., Nordgren, B. L., Urbanski, S. P., Eckhardt, S., Stohl, A., Tunved, P., Crepinsek, S., Jefferson, A., Sharma, S., Nøjgaard, J. K., and Skov, H.: Wildfires in northern Eurasia affect the budget of black carbon in the Arctic - a 12-year retrospective synopsis (2002-2013), Atmos. Chem. Phys., 16, 75877604, https://doi.org/10.5194/acp-16-7587-2016, 2016.

Fiebig, M., Lunder, C. R., and Stohl, A.: Tracing biomass burning aerosol from South America to Troll Research Station, Antarctica, Geophys. Res. Lett., 36, L14815, https://doi.org/10.1029/2009GL038531, 2009.

Flanner, M. G., Zender, C. S., Hess, P. G., Mahowald, N. M., Painter, T. H., Ramanathan, V., and Rasch, P. J.: Springtime warming and reduced snow cover from carbonaceous particles, Atmos. Chem. Phys., 9, 2481-2497, https://doi.org/10.5194/acp9-2481-2009, 2009. 
Garrett, T. J, Zhao, C., Dong, X., Mace, G. G., and Hobbs, P. V.: Effects of varying aerosol regimes on lowlevel Arctic stratus, Geophys. Res. Lett., 31, L17105, https://doi.org/10.1029/2004GL019928, 2004.

Glantz, P., Bourassa, A., Herber, A., Iversen, T., Karlsson, J., Kirkevåg, A., Maturilli, M., Seland, Ø., Stebel, K., Struthers, H., Tesche, M., and Thomason, L.: Remote sensing of aerosols in the Arctic for an evaluation of global climate model simulations, J. Geophys. Res., 119, 8169-8188, https://doi.org/10.1002/2013JD021279, 2014.

Hansen, J. and Nazarenko, L.: Soot climate forcing via snow and ice albedos, P. Natl. Acad. Sci. USA, 101, 423-428, https://doi.org/10.1073/pnas.2237157100, 2004.

Hansen, J., Sato, M., and Ruedy, R.: Radiative forcing and climate response, J. Geophys. Res.-Atmos., 102, 6831-6864, https://doi.org/10.1029/96JD03436, 1997.

Hara, K., Osada, K., Kido, M., Hayashi, M., Matsunaga, K., Iwasaka, Y., Yamanouchi, T., Hashida, G., and Fukatsu, T.: Chemistry of sea-salt particles and inorganic halogen species in Antarctic regions: Compositional differences between coastal and inland stations, J. Geophys. Res., 109, D20208, https://doi.org/10.1029/2004JD004713, 2004.

von Hardenberg, J., Vozella, L., Tomasi, C., Vitale, V., Lupi, A., Mazzola, M., van Noije, T. P. C., Strunk, A., and Provenzale, A.: Aerosol optical depth over the Arctic: a comparison of ECHAM-HAM and TM5 with ground-based, satellite and reanalysis data, Atmos. Chem. Phys., 12, 6953-6967, https://doi.org/10.5194/acp-12-6953-2012, 2012.

Hartmann, D., Klein Tank, A., Rusticucci, M., Alexander, L., Broennimann, B., Charabi, Y., Dentener, F., Dlugokencky, E., Easterling, D., Kaplan, A., Soden, B., Thorne, P., Wild, M., and Zhai, P.: Observations: atmosphere and surface, in: Climate Change 2013: The Physical Science Basis. Contribution of Working Group I to the Fifth Assessment Report of the Intergovernmental Panel on Climate Change, edited by: Stocker, T. F., Qin, D., Plattner, G.-K., Tignor, M., Allen, S. K., Boschung, J., Nauels, A., Xia, Y., Bex, V., and Midgley, P. M., Cambridge University Press, Cambridge, UK and New York, NY, USA, 2013.

Haywood, J. M. and Shine, K. P.: The effect of anthropogenic sulfate and soot aerosol on the clear sky planetary radiation budget, Geophys. Res. Lett., 22, 603-606, https://doi.org/10.1029/95GL00075, 1995.

Hirdman, D., Sodemann, H., Eckhardt, S., Burkhart, J. F., Jefferson, A., Mefford, T., Quinn, P. K., Sharma, S., Ström, J., and Stohl, A.: Source identification of short-lived air pollutants in the Arctic using statistical analysis of measurement data and particle dispersion model output, Atmos. Chem. Phys., 10, 669-693, https://doi.org/10.5194/acp-10-669-2010, 2010.

Hodnebrog, Ø., Myhre, G., and Samset, B. H.: How shorter black carbon lifetime alters its climate effect, Nat. Commun., 5, 5065, https://doi.org/10.1038/ncomms6065, 2014.

Holben, B. N., Eck, T. F., Slutsker, I., Tanré, D., Buis, J. P., Setzer, A., Vermote, E., Reagan, J. A., Kaufman, Y. J., Nakajima, T., Lavenu, F., Jankowiak, I., and Smirnov, A.: AERONET - a federated instrument network and data archive for aerosol characterization, Remote Sens. Environ., 66, 1-16, https://doi.org/10.1016/S0034-4257(98)00031-5, 1998.
Iversen, T. and Joranger, E.: Arctic air pollution and large scale atmospheric flows, Atmos. Environ., 19, 2099-2108, https://doi.org/10.1016/0004-6981(85)90117-9, 1985.

Jaeglé, L., Quinn, P. K., Bates, T. S., Alexander, B., and Lin, J.-T.: Global distribution of sea salt aerosols: new constraints from in situ and remote sensing observations, Atmos. Chem. Phys., 11 3137-3157, https://doi.org/10.5194/acp-11-3137-2011, 2011.

Jiao, C., Flanner, M. G., Balkanski, Y., Bauer, S. E., Bellouin, N., Berntsen, T. K., Bian, H., Carslaw, K. S., Chin, M., De Luca, N., Diehl, T., Ghan, S. J., Iversen, T., Kirkevåg, A., Koch, D., Liu, X., Mann, G. W., Penner, J. E., Pitari, G., Schulz, M., Seland, Ø., Skeie, R. B., Steenrod, S. D., Stier, P., Takemura, T., Tsigaridis, K., van Noije, T., Yun, Y., and Zhang, K.: An AeroCom assessment of black carbon in Arctic snow and sea ice, Atmos. Chem. Phys., 14, 2399-2417, https://doi.org/10.5194/acp14-2399-2014, 2014.

Kim, D., Chin, M., Yu, H., Diehl, T., Tan, Q., Kahn, R. A., Tsigaridis, K., Bauer, S. E., Takemura, T., Pozzoli, L., Bellouin, N., Schulz, M., Peyridieu, S., Chédin, A., and Koffi, B.: Sources, sinks, and transatlantic transport of North African dust aerosol: A multimodel analysis and comparison with remote sensing data, J. Geophys. Res., 119, 6259-6277, https://doi.org/10.1002/2013JD021099, 2014.

Kipling, Z., Stier, P., Johnson, C. E., Mann, G. W., Bellouin, N., Bauer, S. E., Bergman, T., Chin, M., Diehl, T., Ghan, S. J., Iversen, T., Kirkevåg, A., Kokkola, H., Liu, X., Luo, G., van Noije, T., Pringle, K. J., von Salzen, K., Schulz, M., Seland, Ø., Skeie, R. B., Takemura, T., Tsigaridis, K., and Zhang, K.: What controls the vertical distribution of aerosol? Relationships between process sensitivity in HadGEM3-UKCA and inter-model variation from AeroCom Phase II, Atmos. Chem. Phys., 16, 2221-2241, https://doi.org/10.5194/acp-16-2221-2016, 2016.

Kirkevåg, A., Iversen, T., Seland, Ø., Hoose, C., Kristjánsson, J. E., Struthers, H., Ekman, A. M. L., Ghan, S., Griesfeller, J., Nilsson, E. D., and Schulz, M.: Aerosol-climate interactions in the Norwegian Earth System Model - NorESM1-M, Geosci. Model Dev., 6, 207-244, https://doi.org/10.5194/gmd-6207-2013, 2013.

Koch, D. and Hansen, J.: Distant origins of Arctic black carbon: A Goddard Institute for Space Studies ModelE experiment, J. Geophys. Res., 110, D04204, https://doi.org/10.1029/2004JD005296, 2005.

Koch, D., Schulz, M., Kinne, S., McNaughton, C., Spackman, J. R., Balkanski, Y., Bauer, S., Berntsen, T., Bond, T. C., Boucher, O., Chin, M., Clarke, A., De Luca, N., Dentener, F., Diehl, T., Dubovik, O., Easter, R., Fahey, D. W., Feichter, J., Fillmore, D., Freitag, S., Ghan, S., Ginoux, P., Gong, S., Horowitz, L., Iversen, T., Kirkevåg, A., Klimont, Z., Kondo, Y., Krol, M., Liu, X., Miller, R., Montanaro, V., Moteki, N., Myhre, G., Penner, J. E., Perlwitz, J., Pitari, G., Reddy, S., Sahu, L., Sakamoto, H., Schuster, G., Schwarz, J. P., Seland, Ø., Stier, P., Takegawa, N., Takemura, T., Textor, C., van Aardenne, J. A., and Zhao, Y.: Evaluation of black carbon estimations in global aerosol models, Atmos. Chem. Phys., 9, 9001-9026, https://doi.org/10.5194/acp-99001-2009, 2009.

Koch, D., Bauer, S. E., Del Genio, A., Faluvegi, G., McConnell, J. R., Menon, S., Miller, R. L., Rind, D., Ruedy, R., Schmidt, G. A., and Shindell, D.: Coupled aerosol-chemistryclimate twentieth-century transient model investigation: trends in 
short-lived species and climate responses, J. Climate, 24, 26932714, https://doi.org/10.1175/2011JCLI3582.1, 2011.

Koffi, B., Schulz, M., Bréon, F.-M., Dentener, F., Steensen, B. M., Griesfeller, J., Winker, D., Balkanski, Y., Bauer, S. E., Bellouin, N., Berntsen, T., Bian, H., Chin, M., Diehl, T., Easter, R., Ghan, S., Hauglustaine, D. A., Iversen, T., Kirkevåg, A., Liu, X., Lohmann, U., Myhre, G., Rasch, P., Seland, Ø., Skeie, R. B., Steenrod, S. D., Stier, P., Tackett, J., Takemura, T., Tsigaridis, K., Vuolo, M. R., Yoon, J., and Zhang, K.: Evaluation of the aerosol vertical distribution in global aerosol models through comparison against CALIOP measurements: AeroCom phase II results, J. Geophys. Res., 121, 7254-7283, https://doi.org/10.1002/2015JD024639, 2016.

Krinner, G., Boucher, O., and Balkanski, Y.: Reduced glacial ice sheet extent in Northern Asia and Alaska owing to deposition of mineral dust on snow, Geophys. Res. Lett., 27, 613-625, https://doi.org/10.1007/s00382-006-0159-z, 2006.

Kristiansen, N. I., Stohl, A., Olivié, D. J. L., Croft, B., Søvde, O. A., Klein, H., Christoudias, T., Kunkel, D., Leadbetter, S. J., Lee, Y. H., Zhang, K., Tsigaridis, K., Bergman, T., Evangeliou, N., Wang, H., Ma, P.-L., Easter, R. C., Rasch, P. J., Liu, X., Pitari, G., Di Genova, G., Zhao, S. Y., Balkanski, Y., Bauer, S. E., Faluvegi, G. S., Kokkola, H., Martin, R. V., Pierce, J. R., Schulz, M., Shindell, D., Tost, H., and Zhang, H.: Evaluation of observed and modelled aerosol lifetimes using radioactive tracers of opportunity and an ensemble of 19 global models, Atmos. Chem. Phys., 16, 3525-3561, https://doi.org/10.5194/acp16-3525-2016, 2016.

Lamarque, J.-F., Bond, T. C., Eyring, V., Granier, C., Heil, A., Klimont, Z., Lee, D., Liousse, C., Mieville, A., Owen, B., Schultz, M. G., Shindell, D., Smith, S. J., Stehfest, E., Van Aardenne, J., Cooper, O. R., Kainuma, M., Mahowald, N., McConnell, J. R., Naik, V., Riahi, K., and van Vuuren, D. P.: Historical (1850-2000) gridded anthropogenic and biomass burning emissions of reactive gases and aerosols: methodology and application, Atmos. Chem. Phys., 10, 7017-7039, https://doi.org/10.5194/acp-10-7017-2010, 2010.

Lamarque, J.-F., Emmons, L. K., Hess, P. G., Kinnison, D. E., Tilmes, S., Vitt, F., Heald, C. L., Holland, E. A., Lauritzen, P. H., Neu, J., Orlando, J. J., Rasch, P. J., and Tyndall, G. K.: CAM-chem: description and evaluation of interactive atmospheric chemistry in the Community Earth System Model, Geosci. Model Dev., 5, 369-411, https://doi.org/10.5194/gmd-5369-2012, 2012.

Lin, G., Penner, J. E., Sillman, S., Taraborrelli, D., and Lelieveld, J.: Global modeling of SOA formation from dicarbonyls, epoxides, organic nitrates and peroxides, Atmos. Chem. Phys., 12, 47434774, https://doi.org/10.5194/acp-12-4743-2012, 2012.

Liu, J., Fan, S., Horowitz, L. W., and Levy, H.: Evaluation of factors controlling long-range transport of black carbon to the Arctic, J. Geophys. Res., 116, D04307, https://doi.org/10.1029/2010JD015145, 2011.

Liu, Z., Vaughan, M., Winker, D., Kittaka, C., Getzewich, B., Kuehn, R., Omar, A., Powell, K., Trepte, C., and Hostetler, C.: The CALIPSO Lidar Cloud and Aerosol Discrimination: Version 2 algorithm and initial assessment of performance, J. Atmos. Ocean. Tech., 26, 1198-1213, https://doi.org/10.1175/2009jtecha1229.1, 2009.
Liu, X., Easter, R. C., Ghan, S. J., Zaveri, R., Rasch, P., Shi, X., Lamarque, J.-F., Gettelman, A., Morrison, H., Vitt, F., Conley, A., Park, S., Neale, R., Hannay, C., Ekman, A. M. L., Hess, P., Mahowald, N., Collins, W., Iacono, M. J., Bretherton, C. S., Flanner, M. G., and Mitchell, D.: Toward a minimal representation of aerosols in climate models: description and evaluation in the Community Atmosphere Model CAM5, Geosci. Model Dev., 5, 709-739, https://doi.org/10.5194/gmd-5-709-2012, 2012.

Liu, X., Ma, P.-L., Wang, H., Tilmes, S., Singh, B., Easter, R. C., Ghan, S. J., and Rasch, P. J.: Description and evaluation of a new four-mode version of the Modal Aerosol Module (MAM4) within version 5.3 of the Community Atmosphere Model, Geosci. Model Dev., 9, 505-522, https://doi.org/10.5194/gmd-9505-2016, 2016.

Ma, P.-L., Rasch, P. J., Fast, J. D., Easter, R. C., Gustafson Jr., W. I., Liu, X., Ghan, S. J., and Singh, B.: Assessing the CAM5 physics suite in the WRF-Chem model: implementation, resolution sensitivity, and a first evaluation for a regional case study, Geosci. Model Dev., 7, 755-778, https://doi.org/10.5194/gmd-7755-2014, 2014.

McCormick, R. A. and Ludwig, J. H.: Climate modification by atmospheric aerosols, Science, 156, 1358-1359, https://doi.org/10.1126/science.156.3780.1358, 1967.

Chin, M., Diehl, T., Dubovik, O., Eck, T. F., Holben, B. N., Sinyuk, A., and Streets, D. G.: Light absorption by pollution, dust, and biomass burning aerosols: a global model study and evaluation with AERONET measurements, Ann. Geophys., 27, 3439-3464, https://doi.org/10.5194/angeo-27-3439-2009, 2009.

Myhre, G., Samset, B. H., Schulz, M., Balkanski, Y., Bauer, S., Berntsen, T. K., Bian, H., Bellouin, N., Chin, M., Diehl, T., Easter, R. C., Feichter, J., Ghan, S. J., Hauglustaine, D., Iversen, T., Kinne, S., Kirkevåg, A., Lamarque, J.-F., Lin, G., Liu, X., Lund, M. T., Luo, G., Ma, X., van Noije, T., Penner, J. E., Rasch, P. J., Ruiz, A., Seland, Ø., Skeie, R. B., Stier, P., Takemura, T., Tsigaridis, K., Wang, P., Wang, Z., Xu, L., Yu, H., Yu, F., Yoon, J.-H., Zhang, K., Zhang, H., and Zhou, C.: Radiative forcing of the direct aerosol effect from AeroCom Phase II simulations, Atmos. Chem. Phys., 13, 1853-1877, https://doi.org/10.5194/acp13-1853-2013, 2013.

Navarro, J. C. A., Varma, V., Riipinen, I., Seland, Ø., Kirkevåg, A., Struthers, H., Iversen, T., Hansson, H. C., and Ekman, A. M. L.: Amplification of Arctic warming by past air pollution reductions in Europe, Nat. Geosci., 9, 277-281, https://doi.org/10.1038/ngeo2673, 2016.

Nilsson, E. D., Rannik, Ü., Swietlicki, E., Leck, C., Aalto, P. P., Zhou, J., and Norman, M.: Turbulent aerosol fluxes over the Arctic Ocean: 2. Wind-driven sources from the sea, J. Geophys. Res., 106, 32139-32154, https://doi.org/10.1029/2000JD900747, 2001.

Ødemark, K., Dalsøren, S. B., Samset, B. H., Berntsen, T. K., Fuglestvedt, J. S., and Myhre, G.: Short-lived climate forcers from current shipping and petroleum activities in the Arctic, Atmos. Chem. Phys., 12, 1979-1993, https://doi.org/10.5194/acp12-1979-2012, 2012.

Omar, A. H., Winker, D. M., Tackett, J. L., Giles, D. M., Kar, J., Liu, Z., Vaughan, M. A., Powell, K. A., and Trepte, C. R.: CALIOP and AERONET aerosol optical depth comparisons: One size fits none, J. Geophys. Res., 118, 4748-4766, https://doi.org/10.1002/jgrd.50330, 2013. 
Pithan, F. and Mauritsen, T.: Arctic amplification dominated by temperature feedbacks in contemporary climate models, Nat. Geosci., 7, 181-184, https://doi.org/10.1038/ngeo2071, 2014.

Quinn, P. K., Bates, T. S., Schulz, K., and Shaw, G. E.: Decadal trends in aerosol chemical composition at Barrow, Alaska: 1976-2008, Atmos. Chem. Phys., 9, 8883-8888, https://doi.org/10.5194/acp-9-8883-2009, 2009.

Remer, L. A., Kaufman, Y. J., Tanré, D., Mattoo, S., Chu, D. A., Martins, J. V., Li, R.-R., Ichoku, C., Levy, R. C., Kleidman, R. G., Eck, T. F., Vermote, E., and Holben, B. N.: The MODIS aerosol algorithm, products, and validation, J. Atmos. Sci., 62, 947-973, https://doi.org/10.1175/JAS3385.1, 2005.

Rignot, E., Bamber, J. L., van den Broeke, M. R., Davis, C., Li, Y., van de Berg, W. J., and van Meijgaard, E.: Recent Antarctic ice mass loss from radar interferometry and regional climate modelling, Nat. Geosci., 1, 106-110, https://doi.org/10.1038/ngeo102, 2008.

Rogers, R. R., Vaughan, M. A., Hostetler, C. A., Burton, S. P., Ferrare, R. A., Young, S. A., Hair, J. W., Obland, M. D., Harper, D. B., Cook, A. L., and Winker, D. M.: Looking through the haze: evaluating the CALIPSO level 2 aerosol optical depth using airborne high spectral resolution lidar data, Atmos. Meas. Tech., 7, 4317-4340, https://doi.org/10.5194/amt-7-4317-2014, 2014.

Samset, B. H. and Myhre, G.: Climate response to externally mixed black carbon as a function of altitude, J. Geophys. Res., 120, 2913-2927, https://doi.org/10.1002/2014JD022849, 2015.

Samset, B. H., Myhre, G., Schulz, M., Balkanski, Y., Bauer, S., Berntsen, T. K., Bian, H., Bellouin, N., Diehl, T., Easter, R. C., Ghan, S. J., Iversen, T., Kinne, S., Kirkevåg, A., Lamarque, J.-F., Lin, G., Liu, X., Penner, J. E., Seland, Ø., Skeie, R. B., Stier, P., Takemura, T., Tsigaridis, K., and Zhang, K.: Black carbon vertical profiles strongly affect its radiative forcing uncertainty, Atmos. Chem. Phys., 13, 2423-2434, https://doi.org/10.5194/acp13-2423-2013, 2013.

Samset, B. H., Myhre, G., Herber, A., Kondo, Y., Li, S. M., Moteki, N., Koike, M., Oshima, N., Schwarz, J. P., Balkanski, Y., Bauer, S. E., Bellouin, N., Berntsen, T. K., Bian, H., Chin, M., Diehl, T., Easter, R. C., Ghan, S. J., Iversen, T., Kirkevåg, A., Lamarque, J. F., Lin, G., Liu, X., Penner, J. E., Schulz, M., Seland, Ø., Skeie, R. B., Stier, P., Takemura, T., Tsigaridis, K., and Zhang, K.: Modelled black carbon radiative forcing and atmospheric lifetime in AeroCom Phase II constrained by aircraft observations, Atmos. Chem. Phys., 14, 12465-12477, https://doi.org/10.5194/acp-1412465-2014, 2014.

Schulz, M., Textor, C., Kinne, S., Balkanski, Y., Bauer, S., Berntsen, T., Berglen, T., Boucher, O., Dentener, F., Guibert, S., Isaksen, I. S. A., Iversen, T., Koch, D., Kirkevåg, A., Liu, X., Montanaro, V., Myhre, G., Penner, J. E., Pitari, G., Reddy, S., Seland, Ø., Stier, P., and Takemura, T.: Radiative forcing by aerosols as derived from the AeroCom present-day and pre-industrial simulations, Atmos. Chem. Phys., 6, 5225-5246, https://doi.org/10.5194/acp6-5225-2006, 2006.

Schutgens, N. A. J., Gryspeerdt, E., Weigum, N., Tsyro, S., Goto, D., Schulz, M., and Stier, P.: Will a perfect model agree with perfect observations? The impact of spatial sampling, Atmos. Chem. Phys., 16, 6335-6353, https://doi.org/10.5194/acp-166335-2016, 2016a.

Schutgens, N. A. J., Partridge, D. G., and Stier, P.: The importance of temporal collocation for the evaluation of aerosol mod- els with observations, Atmos. Chem. Phys., 16, 1065-1079, https://doi.org/10.5194/acp-16-1065-2016, 2016 b.

Screen, J. A. and Simmonds, I.: The central role of diminishing sea ice in recent Arctic temperature amplification, Nature, 464, 1334-1337, https://doi.org/10.1038/nature09051, 2010.

Serreze, M. C. and Barrett, P.: The summer cyclone maximum over the Central Arctic Ocean, J. Climate, 21, 1048-1065, https://doi.org/10.1175/2007JCLI1810.1, 2008.

Shindell, D. and Faluvegi, G.: Climate response to regional radiative forcing during the twentieth century, Nat. Geosci., 2, 294-300, https://doi.org/10.1038/ngeo473, 2009.

Shindell, D. T., Chin, M., Dentener, F., Doherty, R. M., Faluvegi, G., Fiore, A. M., Hess, P., Koch, D. M., MacKenzie, I. A., Sanderson, M. G., Schultz, M. G., Schulz, M., Stevenson, D. S., Teich, H., Textor, C., Wild, O., Bergmann, D. J., Bey, I., Bian, H., Cuvelier, C., Duncan, B. N., Folberth, G., Horowitz, L. W., Jonson, J., Kaminski, J. W., Marmer, E., Park, R., Pringle, K. J., Schroeder, S., Szopa, S., Takemura, T., Zeng, G., Keating, T. J., and Zuber, A.: A multi-model assessment of pollution transport to the Arctic, Atmos. Chem. Phys., 8, 5353-5372, https://doi.org/10.5194/acp-8-5353-2008, 2008.

Skeie, R. B., Berntsen, T., Myhre, G., Pedersen, C. A., Ström, J., Gerland, S., and Ogren, J. A.: Black carbon in the atmosphere and snow, from pre-industrial times until present, Atmos. Chem. Phys., 11, 6809-6836, https://doi.org/10.5194/acp11-6809-2011, 2011.

Stier, P., Feichter, J., Kinne, S., Kloster, S., Vignati, E., Wilson, J., Ganzeveld, L., Tegen, I., Werner, M., Balkanski, Y., Schulz, M., Boucher, O., Minikin, A., and Petzold, A.: The aerosol-climate model ECHAM5-HAM, Atmos. Chem. Phys., 5, 1125-1156, https://doi.org/10.5194/acp-5-1125-2005, 2005.

Stier, P., Schutgens, N. A. J., Bellouin, N., Bian, H., Boucher, O., Chin, M., Ghan, S., Huneeus, N., Kinne, S., Lin, G., Ma, X., Myhre, G., Penner, J. E., Randles, C. A., Samset, B., Schulz, M., Takemura, T., Yu, F., Yu, H., and Zhou, C.: Host model uncertainties in aerosol radiative forcing estimates: results from the AeroCom Prescribed intercomparison study, Atmos. Chem. Phys., 13, 3245-3270, https://doi.org/10.5194/acp-13-3245-2013, 2013.

Stohl, A.: Characteristics of atmospheric transport into the Arctic troposphere, J. Geophys. Res., 111, D11306, https://doi.org/10.1029/2005JD006888, 2006.

Stohl, A. and Sodemann, H.: Characteristics of atmospheric transport into the Antarctic troposphere, J. Geophys. Res., 115, D02305, https://doi.org/10.1029/2009JD012536, 2010.

Stohl, A., Klimont, Z., Eckhardt, S., Kupiainen, K., Shevchenko, V. P., Kopeikin, V. M., and Novigatsky, A. N.: Black carbon in the Arctic: the underestimated role of gas flaring and residential combustion emissions, Atmos. Chem. Phys., 13, 8833-8855, https://doi.org/10.5194/acp-13-8833-2013, 2013.

Stone, R. S., Herber, A., Vitale, V., Mazzola, M., Lupi, A., Schnell, R. C., Dutton, E. G., Liu, P. S. K., Li, S. M., Dethloff, K., Lampert, A., Ritter, C., Stock, M., Neuber, R., and Maturilli, M.: A three-dimensional characterization of Arctic aerosols from airborne Sun photometer observations: PAM-ARCMIP, April 2009, J. Geophys. Res., 115, D13203, https://doi.org/10.1029/2009JD013605, 2010.

Stone, R., Sharma, S., Herber, A., Eleftheriadis, K., and Nelson, D.: A characterization of Arctic aerosols on the basis of aerosol op- 
tical depth and black carbon measurements, Elem. Sci. Anth., 2, 27, https://doi.org/10.12952/journal.elementa.000027, 2014.

Szopa, S., Balkanski, Y., Schulz, M., Bekki, S., Cugnet, D., Fortems-Cheiney, A., Turquety, S., Cozic, A., Déandreis, C., Hauglustaine, D., Idelkadi, A., Lathière, J., Lefevre, F., Marchand, M., Vuolo, R., Yan, N., and Dufresne, J. L.: Aerosol and ozone changes as forcing for climate evolution between 1850 and 2100, Clim. Dynam., 40, 2223-2250, https://doi.org/10.1007/s00382-012-1408-y, 2013.

Takemura, T., Nozawa, T., Emori, S., Nakajima, T. Y., and Nakajima, T.: Simulation of climate response to aerosol direct and indirect effects with aerosol transport-radiation model, J. Geophys. Res., 110, D02202, https://doi.org/10.1029/2004JD005029, 2005.

Textor, C., Schulz, M., Guibert, S., Kinne, S., Balkanski, Y., Bauer, S., Berntsen, T., Berglen, T., Boucher, O., Chin, M., Dentener, F., Diehl, T., Easter, R., Feichter, H., Fillmore, D., Ghan, S., Ginoux, P., Gong, S., Grini, A., Hendricks, J., Horowitz, L., Huang, P., Isaksen, I., Iversen, I., Kloster, S., Koch, D., Kirkevåg, A., Kristjansson, J. E., Krol, M., Lauer, A., Lamarque, J. F., Liu, X., Montanaro, V., Myhre, G., Penner, J., Pitari, G., Reddy, S., Seland, Ø., Stier, P., Takemura, T., and Tie, X.: Analysis and quantification of the diversities of aerosol life cycles within AeroCom, Atmos. Chem. Phys., 6, 1777-1813, https://doi.org/10.5194/acp-6-17772006, 2006.

Tomasi, C., Vitale, V., Lupi, A., Di Carmine, C., Campanelli, M., Herber, A., Treffeisen, R., Stone, R. S., Andrews, E., Sharma, S., Radionov, V., von Hoyningen-Huene, W., Stebel, K., Hansen, G. H., Myhre, C. L., Wehrli, C., Aaltonen, V., Lihavainen, H., Virkkula, A., Hillamo, R., Ström, J., Toledano, C., Cachorro, V. E., Ortiz, P., de Frutos, A. M., Blindheim, S., Frioud, M., Gausa, M., Zielinski, T., Petelski, T., and Yamanouchi, T.: Aerosols in polar regions: a historical overview based on optical depth and in situ observations, J. Geophys. Res., 112, D16205, https://doi.org/10.1029/2007JD008432, 2007.

Tomasi, C., Kokhanovsky, A. A., Lupi, A., Ritter, C., Smirnov, A., O’Neill, N. T., Stone, R. S., Holben, B. N., Nyeki, S., Wehrli, C., Stohl, A., Mazzola, M., Lanconelli, C., Vitale, V., Stebel, K., Aaltonen, V., de Leeuw, G., Rodriguez, E., Herber, A. B., Radionov, V. F., Zielinski, T., Petelski, T., Sakerin, S. M., Kabanov, D. M., Xue, Y., Mei, L., Istomina, L., Wagener, R., McArthur, B., Sobolewski, P. S., Kivi, R., Courcoux, Y., Larouche, P., Broccardo, S., and Piketh, S. J.: Aerosol remote sensing in polar regions, Earth-Sci. Rev., 140, 108-157, https://doi.org/10.1016/j.earscirev.2014.11.001, 2015.

Tsigaridis, K., Daskalakis, N., Kanakidou, M., Adams, P. J., Artaxo, P., Bahadur, R., Balkanski, Y., Bauer, S. E., Bellouin, N., Benedetti, A., Bergman, T., Berntsen, T. K., Beukes, J. P., Bian, H., Carslaw, K. S., Chin, M., Curci, G., Diehl, T., Easter, R. C., Ghan, S. J., Gong, S. L., Hodzic, A., Hoyle, C. R., Iversen, T., Jathar, S., Jimenez, J. L., Kaiser, J. W., Kirkevåg, A., Koch, D., Kokkola, H., Lee, Y. H., Lin, G., Liu, X., Luo, G., Ma, X., Mann, G. W., Mihalopoulos, N., Morcrette, J.-J., Müller, J.-F., Myhre, G., Myriokefalitakis, S., Ng, N. L., O’Donnell, D., Penner, J. E., Pozzoli, L., Pringle, K. J., Russell, L. M., Schulz, M., Sciare, J., Seland, Ø., Shindell, D. T., Sillman, S., Skeie, R. B., Spracklen, D., Stavrakou, T., Steenrod, S. D., Takemura, T., Tiitta, P., Tilmes, S., Tost, H., van Noije, T., van Zyl, P. G., von Salzen, K., Yu, F., Wang, Z., Wang, Z., Zaveri, R. A., Zhang, H.,
Zhang, K., Zhang, Q., and Zhang, X.: The AeroCom evaluation and intercomparison of organic aerosol in global models, Atmos. Chem. Phys., 14, 10845-10895, https://doi.org/10.5194/acp-1410845-2014, 2014.

Twomey, S.: The influence of pollution on the shortwave albedo of clouds, J. Atmos. Sci., 34, 1149-1152, https://doi.org/10.1175/15200469(1977)034<1149:TIOPOT>2.0.CO;2, 1977.

Vignati, E., Wilson, J., and Stier, P.: M7: An efficient size-resolved aerosol microphysics module for large-scale aerosol transport models, J. Geophys. Res., 109, D22202, https://doi.org/10.1029/2003JD004485, 2004.

Wang, H., Easter, R. C., Rasch, P. J., Wang, M., Liu, X., Ghan, S. J., Qian, Y., Yoon, J.-H., Ma, P.-L., and Vinoj, V.: Sensitivity of remote aerosol distributions to representation of cloud-aerosol interactions in a global climate model, Geosci. Model Dev., 6, 765-782, https://doi.org/10.5194/gmd-6-765-2013, 2013.

Winker, D. M., Vaughan, M. A., Omar, A., Hu, Y. X., Powell, K. A., Liu, Z. Y., Hunt, W. H., and Young, S. A.: Overview of the CALIPSO mission and CALIOP data processing algorithms, J. Atmos. Ocean. Tech., 26, 2310-2323, https://doi.org/10.1175/2009jtecha1281.1, 2009.

Winker, D. M., Tackett, J. L., Getzewich, B. J., Liu, Z., Vaughan, M. A., and Rogers, R. R.: The global 3-D distribution of tropospheric aerosols as characterized by CALIOP, Atmos. Chem. Phys., 13, 3345-3361, https://doi.org/10.5194/acp-133345-2013, 2013.

Yang, Q., Bitz, C. M., and Doherty, S. J.: Offsetting effects of aerosols on Arctic and global climate in the late 20th century, Atmos. Chem. Phys., 14, 3969-3975, https://doi.org/10.5194/acp14-3969-2014, 2014.

Yu, F. and Luo, G.: Simulation of particle size distribution with a global aerosol model: contribution of nucleation to aerosol and CCN number concentrations, Atmos. Chem. Phys., 9, 76917710, https://doi.org/10.5194/acp-9-7691-2009, 2009.

Zhang, H., Wang, Z., Wang, Z., Liu, Q., Gong, S., Zhang, X., Shen, Z., Lu, P., Wei, X., Che, H., and Li, L.: Simulation of direct radiative forcing of aerosols and their effects on East Asian climate using an interactive AGCM-aerosol coupled system, Clim. Dynam., 38, 1675-1693, https://doi.org/10.1007/s00382011-1131-0, 2012a.

Zhang, K., O’Donnell, D., Kazil, J., Stier, P., Kinne, S., Lohmann, U., Ferrachat, S., Croft, B., Quaas, J., Wan, H., Rast, S., and Feichter, J.: The global aerosol-climate model ECHAM-HAM, version 2: sensitivity to improvements in process representations, Atmos. Chem. Phys., 12, 8911-8949, https://doi.org/10.5194/acp-12-8911-2012, 2012b.

Zhou, C., Penner, J. E., Flanner, M. G., Bisiaux, M. M., Edwards, R., and McConnell, J. R.: Transport of black carbon to polar regions: Sensitivity and forcing by black carbon, Geophys. Res. Lett., 39, L22804, https://doi.org/10.1029/2012GL053388, 2012. 